\title{
Role of Autophagy and Apoptosis in Non-Small-Cell Lung Cancer
}

\author{
Guangbo Liu ${ }^{1, *}$, Fen Pei ${ }^{1}$, Fengqing Yang ${ }^{2}$, Lingxiao Li ${ }^{3}$, Amit Dipak Amin ${ }^{3}$, Songnian Liu ${ }^{4}$, \\ J. Ross Buchan ${ }^{1, *}$ and William C. Cho ${ }^{5, *}$ \\ 1 Department of Molecular and Cellular Biology, University of Arizona, Tucson, AZ 85721, USA; \\ peifen1990@gmail.com \\ 2 Department of Obstetrics and Gynecology, Dong'e No. 4 People's Hospital, Liaocheng 252200, China; \\ yfqldz@gmail.com \\ 3 Department of Medicine, Division of Hematology-Oncology, Sylvester Comprehensive Cancer Center, \\ University of Miami Miller School of Medicine, Miami, FL 33136, USA; lingxiaoli@med.miami.edu (L.L.); \\ amitdipakamin@med.miami.edu (A.D.A.) \\ 4 Department of Chemical and Life Science Engineering, Virginia Commonwealth University, Richmond, \\ VA 23284, USA; sliu6@vcu.edu \\ 5 Department of Clinical Oncology, Queen Elizabeth Hospital, Kowloon, Hong Kong, China \\ * Correspondence: guangboliu@email.arizona.edu (G.L.); rbuchan@email.arizona.edu (J.R.B.); \\ chocs@ha.org.hk (W.C.C.); Tel.: +1-858-900-7234 (G.L.); Fax: +1-520-621-9903 (G.L.)
}

Academic Editor: Anthony Lemarié

Received: 6 December 2016; Accepted: 3 February 2017; Published: 10 February 2017

\begin{abstract}
Non-small-cell lung cancer (NSCLC) constitutes 85\% of all lung cancers, and is the leading cause of cancer-related death worldwide. The poor prognosis and resistance to both radiation and chemotherapy warrant further investigation into the molecular mechanisms of NSCLC and the development of new, more efficacious therapeutics. The processes of autophagy and apoptosis, which induce degradation of proteins and organelles or cell death upon cellular stress, are crucial in the pathophysiology of NSCLC. The close interplay between autophagy and apoptosis through shared signaling pathways complicates our understanding of how NSCLC pathophysiology is regulated. The apoptotic effect of autophagy is controversial as both inhibitory and stimulatory effects have been reported in NSCLC. In addition, crosstalk of proteins regulating both autophagy and apoptosis exists. Here, we review the recent advances of the relationship between autophagy and apoptosis in NSCLC, aiming to provide few insights into the discovery of novel pathogenic factors and the development of new cancer therapeutics.
\end{abstract}

Keywords: non-small-cell lung cancer (NSCLC); apoptosis; autophagy; crosstalk; p53; mammalian target of rapamycin (mTOR); endoplasmic reticulum (ER) stress

\section{Introduction}

Lung cancer is one of the leading causes of all cancer-related deaths. About 1.6 million people died from lung cancer in 2012, which accounts for $19 \%$ of all cancer death worldwide. In fact, lung cancer deaths alone exceed the sum of the next three most prevalent cancers death (colon, breast, and prostate) [1]. Lung cancer's poor prognosis is partly due to late diagnosis that results from the lack of any obvious symptoms during early disease progression. In addition, multiple gene alterations including mutations, amplifications, deletions and fusions identified in NSCLC aggravate the abnormalities of signaling pathways and physiological activities. Histological classification sub-divides lung cancers into two subgroups, non-small-cell lung cancer (NSCLC, 85\%) and small-cell lung cancer (SCLC, 15\%), both of which are therapeutically treated differently. NSCLC is further 
divided into three main histological subtypes including squamous-cell carcinoma, adenocarcinoma, and large-cell carcinoma. Squamous-cell carcinoma accounts for $20 \%-30 \%$ and is usually identified in the center of the lung close to the air tube. Adenocarcinoma accounts for $40 \%-70 \%$ and is found at the outer area of the lung. Large-cell carcinoma accounts for $10 \%-15 \%$ of cases and can be found throughout the lung [2].

Autophagy and apoptosis play an important role during lung cancer progression. Macroautophagy (hereafter called autophagy) is a "self-eating" process, engulfing cytoplasmic proteins, complexes or organelles into the autophagosome (a cytoplasmic double membrane structure). The autophagosome is either incorporated into the late endosome, or is transported to, and fuses with, the lysosome to generate the autolysosome, where cargos are then released and degraded by acidic hydrolases. The degradation products generated, including nucleotides, amino acids, fatty acids and sugars, can then be transported back and recycled into general cell metabolism [3-5].

Apoptosis has been intensively investigated in the past three decades and is established as the major mechanism of development and programmed cell death. In 1972, Kerr et al. first used the term "apoptosis" to describe a distinct morphology of cell death [6]. Apoptosis is regulated by intracellular and/or extracellular signals and characterized by morphological changes of the cell targeted for death that include nuclear fragmentation and condensation, mitochondrial outer membrane permeabilization (MOMP), membrane blebbing, cell shrinkage and apoptotic body formation [7]. Studies in different model systems uncovered the essential role of apoptosis in normal development and homeostasis. During the development of the nematode Caenorhabditis elegans, for example, 131 cells undergo programmed cell death [8]. Programmed cell death is also required for eliminating interdigital webs in higher vertebrates during digit formation [9]. Moreover, apoptosis also plays a defensive role in immune reactions or eliminating damaged cells, serving as a quality control for homeostasis [10].

Autophagy can play a positive and negative role in promoting apoptosis in NSCLC. Generally, inhibition of autophagy limits the ability of cells to overcome stress and maintain homeostasis [11]. However, there are instances where autophagy promotes cell death, and these have been described elsewhere [12-17]. The interplay of autophagy and apoptosis in NSCLC is complicated. Indeed, autophagy functions as a double-edged sword in carcinogenesis. On the one hand, autophagy is always inhibited by different oncoproteins, such as AKT, PI3K, Bcl-1 and mutant p53, which may prevent excessive protein degradation in starved or stressed tumor cells. On the other hand, persistent activation of autophagy causes autophagic programmed cell death or apoptosis [18,19]. The processes of autophagy and apoptosis are discussed in detail below.

\section{Autophagy and Apoptosis}

\subsection{The Mechanism of Autophagy}

Autophagy starts with the formation of the isolation membrane/phagophore, which is often found at the contact sites between the endoplasmic reticulum and mitochondria [20]. The subsequent phases of the autophagic pathway include vesicle elongation, autophagosome maturation (sequestration of cargo), autophagosome-lysosome fusion and degradation [21]. Multiple molecular complexes perform the key processes of each phase of autophagy, including (but not limited to) ULK1 complex (ULK1, FIP200, ATG13L and ATG101), VPS34 complex (VPS15, VPS34, Beclin-1, ATG14 or UVRAG), ubiquitin-like conjugation system (ATG5, ATG12, ATG16L), and LC3 (type II light chain 3) conjugation system [22].

In physiological situations, autophagy is always occurring at a basal level, functioning as an intracellular quality control system to maintain homeostasis where any superfluous and/or damaged protein entities are removed [7]. Autophagic flux is always activated at, for example, transit cellular stress and nutrient starvation and is often visualized by the accumulation of the autophagosome [7,22-25]. The most commonly assessment to evaluate autophagic activity is the autophagosome accumulation, which can be reflect either accelerated autophagosome formation to 
increase the autophagic flux or slowed autophagosome clearance in the lysosome to decrease the autophagic flux [26]. For a detailed review of the apoptosis and autophagy pathway, please see other excellent recent reviews $[5,7,10]$.

\subsection{The Mechanism of Apoptosis}

Apoptosis is the main and most well-studied form of programmed cell death. Caspases are ubiquitously expressed cysteine proteases that play a central role in apoptosis. In physiological scenarios, caspases are expressed as inactive forms with little protease activity [27,28]. Death-inducing stimuli lead to the cleavage at aspartic residues of caspases and removal of the N-terminal inhibitory domain, resulting in the demolition phase of apoptosis [28]. While caspases are predominantly associated with apoptosis, it is worth noting that some caspases are also involved in cytokine maturation and innate immunity [29].

Two core pathways of apoptosis include the extrinsic death receptor pathway and the intrinsic mitochondria pathway. The extrinsic pathway is initiated by the activation of multiple death receptors, such as Fas (CD95/Apo1), tumor necrosis factor receptors (TNFRs), and TNF-related apoptosis-inducing ligand receptors (TRAILRs). When death stimuli occur, the cytoplasmic domains of death receptors recruit death domain-containing adaptor proteins, such as FADD (Fas-associated protein with death domain) and TRADD (TNFR1-associated death domain), which then interact with pro-caspase- 8 by the death effector domain (DED) to form the death-inducing signaling complex (DISC) to propagate the apoptotic signal. Pro-caspase- 8 is activated in the DISC, which then directly proteolytically cleaves and activates caspase- 3 . Activated caspase- 8 additionally triggers mitochondrial damage by the cleavage of the BH3-only protein BID to generate truncated BID (tBID) [30]. Activation of the intrinsic mitochondria pathway is marked by mitochondrial outer membrane permeabilization (MOMP), which in turn releases cytochrome $\mathrm{c}$ to the cytoplasm. Apaf- 1 and pro-caspase- 9 are recruited to cytoplasmic cytochrome $\mathrm{c}$ to generate the apoptosome with a 1:1:1 molar ratio [31]. The apoptosome activates the apoptosis effector protein caspases-3, -6 and -7 , resulting in apoptosis.

The intrinsic apoptotic pathway is also tightly regulated by the Bcl-2 family proteins, which is comprised of pro-apoptotic members (such as Bax, Bak, Bad, Bcl-Xs, BID, Bik, Bim, HRK, Noxa and PUMA) and anti-apoptotic members (such as Bcl-2, Bcl-Xl, Bcl-W, Bfl-1 and MCL-1) [32]. Multiple cellular stresses, including DNA damage, energy starvation and hypoxia, dephosphorylates and cleaves these pro-apoptotic proteins, leading to their translocation to the mitochondria and consequent apoptosis. In addition, BH3-only proteins, such as Bim and BID, act through activation of pro-apoptotic Bax and Bak to induce apoptosis. Furthermore, indirect suppression of the anti-apoptotic proteins, such as Bad, Bik, Noxa, HRK and PUMA, in the mitochondria and endoplasmic reticulum can also cause apoptosis. Abnormalities in Bcl-2 family proteins are seen for example in NSCLC, where amplification of the anti-apoptotic Bcl-2 and MCL-1 proteins is associated with clinical drug resistance [33,34].

\section{Crosstalk between Autophagy and Apoptosis}

\subsection{Linking Autophagy and Apoptosis}

Autophagy and apoptosis occur when cells are under stress [7]. Normally, autophagy precedes apoptosis and maintains cell homeostasis. Apoptosis or other types of programmed cell death, is activated once stress is prolonged for a critical duration or exceeds the intensity threshold [7,11].

Interestingly, a substantial amount of evidence suggests that autophagy itself may be another cell death mechanism, termed autophagic cell death (ACD), highlighting a potential pro-death role for autophagy $[7,13]$. ACD, characterized by the absence of chromatin condensation, accumulated cytoplasmic vacuolization, LC3 lipidation and caspase-independent apoptosis, is usually suppressed by autophagy pathway inhibitors or knock out/down of core autophagy genes [7]. Notably, a few other forms of cell death are also termed "ACD", which make it confusing and controversial [26]. 
For example, autophagy-associated cell death (massive cytoplasmic vacuolization is accompanied with cell death), autophagy-mediated cell death (autophagy triggers apoptosis pathway activation) and a distinct apoptotic mechanism (independent of apoptosis and necrosis) are also sometimes called "ACD" [26]. Furthermore, the autophagic roles of caspases and apoptotic functions of autophagy-related proteins (ATGs) create further overlap between both processes (see below) [35]. Autophagy may thus function as a guardian or executioner of apoptosis depending on the surrounding micro-environment, therapeutic intervention and the stage of carcinoma.

\subsection{Beclin-1/Bcl-2 and FLIP (FADD-Like IL-1 $\beta$-Converting Enzyme-Inhibitory Protein)}

Various factors function in both apoptosis and autophagy. Beclin-1, for example, binds to Bcl-2 and inhibits both autophagy and apoptosis at basal levels. Nutrient starvation activates JNK1 (C-Jun $\mathrm{N}$-terminal protein kinase 1), which phosphorylates the regulatory loop of Bcl-2 and then severs the interaction between Bcl-2 and Beclin-1. Isolated Beclin-1promotes autophagy by activation of core autophagic components, such as lipid kinase VPS34 and Beclin-1/VPS34/vps15 core complex. In addition, phosphorylated Bcl-2 interacts with Bax and maintains the integrity of mitochondrial membrane, promoting the anti-apoptotic functions [36]. However, extended starvation results in JNK1-mediated Bcl-2 hyper-phosphorylation, which leads to the dissociation with Bax and activation of caspase-3-mediated apoptosis [37]. In addition, cardiac glycoside ouabain, a Na/K-ATPase inhibitor, induces Bcl-2 reduction due to JNK1 activation, which disrupts Bcl-2/Beclin-1 interaction and results in caspase-independent autophagic cell death in NSCLC cells [38].

FLIP (FADD-like IL-1 $\beta$-converting enzyme-inhibitory protein) is an anti-apoptotic protein involved in death receptor-mediated extrinsic pathway [39]. In addition, FLIP inhibits LC3 lipidation by competitive interaction with ATG3, which in turn blocks autophagy. Conversely, induction of autophagy suppresses FLIP and ATG3 interaction [40].

\subsection{The Role of Autophagy-Related Proteins (ATGs) in Apoptosis and Autophagy}

Autophagy is a highly conserved process in organisms, from yeast to humans, which relies on the function of a core set of ATGs [41]. However, apoptotic roles for several ATGs have also been recently described. For example, Atg4 is a cysteine protease identified in yeast that is involved in autophagosome formation. ATG4D is its human ortholog which is cleaved by caspase-3 during apoptosis. The C-terminal of cleaved ATG4D contains a putative BH3 domain, which is recruited to the mitochondria to stimulate apoptosis [42]. In addition, ATG12-ATG3 is required for the formation of the autophagosome. The complex can also localize at the outer membrane of mitochondria to stimulate intrinsic apoptosis [43]. Furthermore, covalent conjugation of ATG5 and ATG12 is involved in an ubiquitylation-like process that is essential for autophagy induction [44]. Interestingly, ATG5 and ATG12 can induce apoptosis upon stress. ATG5 overexpression promotes tumor cell sensitivity to chemotherapy, whereas inhibition of ATG5 increases resistance to chemotherapy [35]. In addition, apoptosis induction inhibits the autophagic role of ATG5 and promotes ATG5 cleavage by calpains. The amino-terminal cleaved product of ATG5 translocates from the cytoplasm to mitochondria, resulting in its association with $\mathrm{Bcl}-\mathrm{Xl}$ and the release of cytochrome $\mathrm{c}$ to the cytoplasm, leading to apoptosis [45]. Following apoptotic stimuli, non-conjugated ATG12 binds to MCL-1 and Bcl-2, thereby inhibiting their anti-apoptotic functions and augmenting mitochondrial-mediated intrinsic apoptosis [46].

\subsection{The Role of Caspases in Autophagy and Apoptosis}

Recently, it has been shown that caspases participate in the regulation of autophagy as well $[35,47]$. Activated caspases result in autophagy inhibition by breaking down autophagy-associated proteins, such as Beclin-1, ATG5 and p62. Caspase-8, a well-known essential apoptotic protein, regulates autophagy by cleavage of ATG3, leading to the pro-autophagic inhibition. Prevention of caspase- 8 cleavage and activation induces hyperactive autophagy in T cells [48]. Caspase-9, 
another apoptosis protein associated with apoptosome formation and intrinsic apoptosis pathway, induces autophagy by increasing LC3 lipidation via an interaction with ATG7 [35,41]. Conversely, the combination of caspase- 9 and ATG7 inhibits translocation of caspase- 9 to the apoptosome, hence preventing apoptosis [35,41]. In addition, the predominant apoptotic protein caspase-3 also shows autophagic activity. Caspase- 3 cleaves Beclin- 1 at TDVD ${ }^{133}$ and DQLD ${ }^{149}$, yielding fragments lacking pro-autophagic capacity. It is worth noting that the C-terminal of Beclin-1 localizes at the mitochondria and augments apoptosis [49]. Therefore, activated caspases not only perform apoptosis, but also hinder or reinforce autophagy by their interaction with and cleavage of autophagy-related proteins. Immunoprecipitation of key apoptotic proteins, such as caspase-8, caspase-3 and caspase-9 upon stimulation—including nutrient starvation, hypoxia or chemical treatment-will help to further our understanding of the crosstalk between autophagy and apoptosis.

\section{The Abnormality of Genome in Non-Small-Cell Lung Cancer (NSCLC)}

Nowadays, the ability to sequence the genomes of NSCLC patients has given a greater insight into the disease through the identification of aberrant genes, leading to new biomarkers and therapeutic targets [2,50]. Table 1 summaries known mutant genes in both adenocarcinoma and squamous-cell carcinoma. The most commonly mutated gene is $p 53$, seen in $45 \%-70 \%$ of adenocarcinomas and $60 \%-80 \%$ of squamous-cell carcinoma. Other aberrant genes, such as EGFR, KRAS, LKB1 and PTEN, are closely associated with the mTOR regulation network. Hence, we will discuss p53 in this section and mTOR pathway in Section 5.

Table 1. Genetic abnormalities in non-small-cell lung cancer (NSCLC).

\begin{tabular}{ccc}
\hline Genetic Alterations & Incidence (\%) & Incidence (\%) \\
\hline Mutation & Adenocarcinomas & Squamous-Cell Carcinoma \\
\hline$p 53$ & $45-70$ & $60-80$ \\
KRAS & $10-30$ & \\
$E G F R$ & $10-40$ & 19 \\
LKB1 & 34 & \\
$M E T$ & 14 & 4 \\
$D D R 2$ & & \\
$H E R 2$ & 4 & 3 \\
BRAF & $2-10$ & $3-10$ \\
PTEN & $2-5$ & $2-18$ \\
PIK3CA & 2 & 2 \\
AKT1 & & \\
Fusion & 7 & \\
$A L K$ & $1-2$ & \\
ROS1 & $1-2$ & \\
RET & & \\
Amplification & $5-20$ & $3-21$ \\
MET & 15 & 15 \\
TITF-1 & 15 & 30 \\
EGFR & 6 & 2 \\
HER2 & 6 & $25-45$ \\
PIK3CA & & $16-25$ \\
FGFR1 & & \\
Deletion & & 51 \\
CDKN2A & $20-40$ & $20-60$ \\
PTEN & &
\end{tabular}

\section{1. p53 Function}

p53 is normally located in the cytoplasm and translocates to the nucleus following the direct or indirect phosphorylation by a variety of kinases upon cellular stress [51]. Phosphorylated nuclear 
p53 forms a tetramer and functions as a transcription factor that promotes the expression of a variety of pro-apoptotic proteins mediating both death receptor and mitochondrial pathways, such as Fas, Bax, Bim, Noxa and PUMA (Figure 1) [52]. In addition, MOMP can also be modified by cytoplasmic monomeric p53 via regulating MOMP-governing Bcl-2 family proteins. Here, p53 translocates to the mitochondrial surface and directly binds to Bcl-2 family proteins, leading to apoptosis [53,54]. The intrinsic pathway plays the major role in p53-mediated apoptosis, although p53 can also regulate the extrinsic pathway. Besides controlling the Bcl-2 family, p53 also promotes Apaf-1 and caspase-6 expression, resulting in apoptosis [55]. Recently, the apoptotic effect of cytoplasmic p53 has been associated with the endoplasmic reticulum (ER), which is a critical organelle modulating autophagy and apoptosis, discussed further in Section 6. Wild-type p53 translocates to the ER and mitochondria-associated ER membranes during the stimulation, and directly interacts with the sarco/ER Ca ${ }^{2+}$-ATPase (SERCA) pump to increase $\mathrm{Ca}^{2+}$ load. More $\mathrm{Ca}^{2+}$ accordingly transfers to the mitochondria, leading to mitochondrial morphology alterations and apoptosis due to $\mathrm{Ca}^{2+}$ overload [56,57].

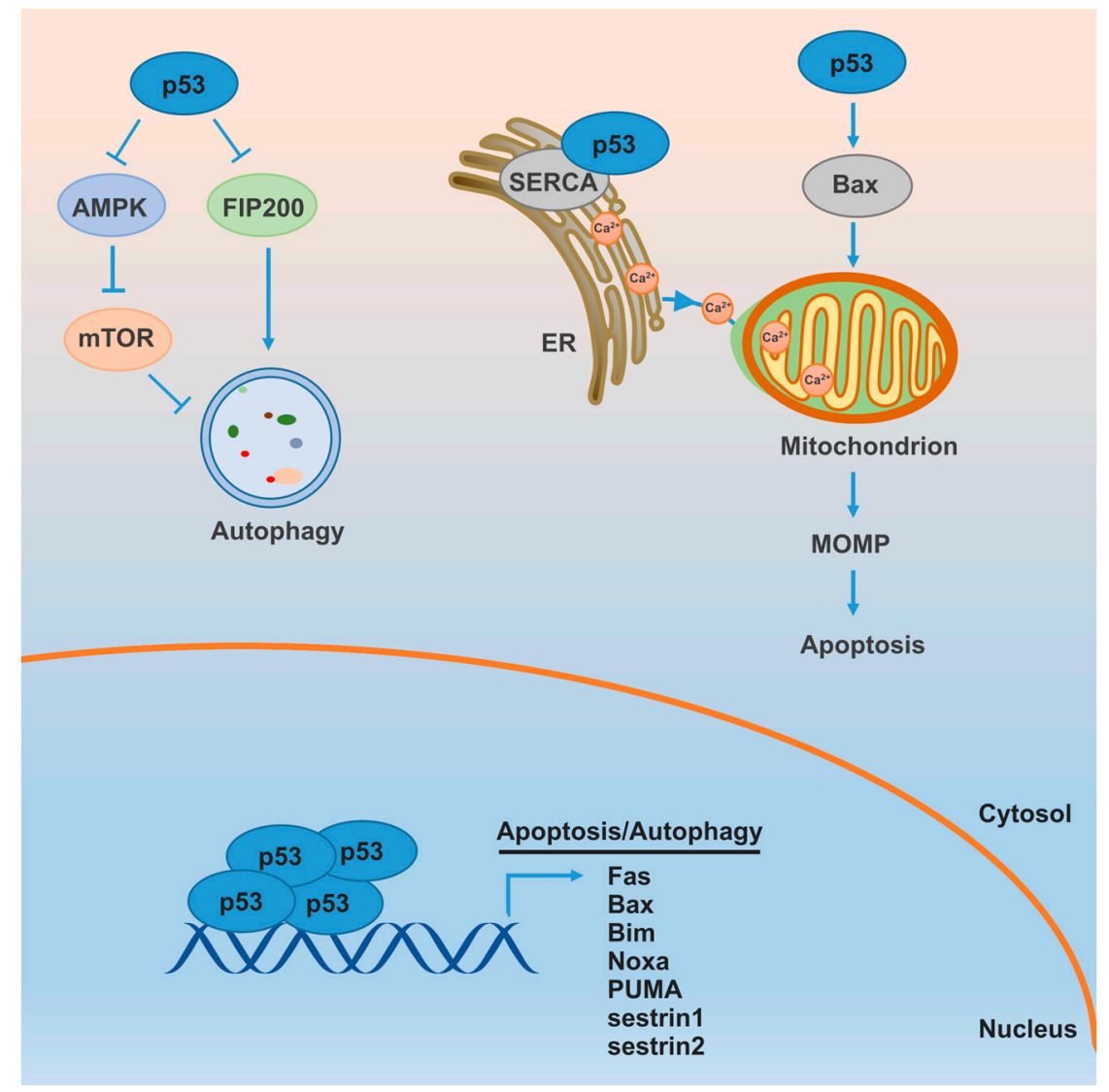

Figure 1. p53 promotes apoptosis and inhibits autophagy. Nuclear p53 induces autophagy and the transcription of multiple apoptotic genes that function in both extrinsic and intrinsic apoptosis pathway. Cytoplasmic pools of p53 directly or indirectly trigger MOMP and lead to apoptosis. In addition, cytoplasmic p53 inhibits autophagy by FIP200 or the AMPK/mTOR pathway.

p53 can also regulate autophagy. Nuclear p53 promotes autophagy whereas cytoplasmic p53 inhibits it. Following stress, p53 translocates to the nucleus and promotes sestrin1 and sestrin2 transcription and expression, which can act through AMPK-TSC2-mTOR pathway to stimulate autophagy [58]. Cytosolic p53 interacts with the autophagy component FIP200 and competitively inactivates autophagy. The anti-autophagic role of p53 can also be modulated by inhibition of AMP-dependent kinase (positive regulator of autophagy) and activation of mTORC1 (negative 
regulator of autophagy) [59]. Cell lines and mouse model show that blocking p53 expression with pifithrin- $\alpha$ induces autophagy [60]. p53 knockout cells display enhanced autophagy compared to its wild-type counterpart as well. Conversely, inhibition of p53 degradation prevents the induction of autophagy. Furthermore, p53 inhibition-mediated autophagy protects cells from apoptosis upon hypoxia or nutrient starvation, indicating an anti-apoptotic role of autophagy [61].

\section{2. $p 53$ Mutation}

The frequent loss of heterozygosity ( $\mathrm{LOH}$ ) of p53 on chromosome $17 \mathrm{p} 13$ suggests $\mathrm{p} 53$ is likely involved in the pathogenesis of NSCLC [62]. Hence, understanding the p53 network may ultimately allow scientists and clinicians to develop novel drugs and therapeutics. p53 was identified in 1979 and functioned as the tumor-suppressor gene although it was initially considered as the oncogene for the first ten years [63-66]. Wild-type p53 not only limits its transforming ability, but also inhibits transformation mediated by the classic oncogenic protein, KRAS [62]. Mutant p53 is commonly observed in tumors with poor prognosis, increased malignancy and resistance to treatment [67-73]. Experiments in both rodent and human cell lines show that mutant p53 can transform primary cultured cells through loss of its tumor-suppressive functions [74]. Loss of function (LOF) with wild-type p53 and gain of function (GOF) with mutant p53 may also aid in tumorigenesis. Abolishing mutant p53's oncogenic properties or conversion of mutant p53 to the wild-type form is a potential therapeutic approach [71,75].

Different mutant p53 alleles can localize to the nucleus and/or cytoplasm, which are unable or able to inhibit autophagy depending on cell context and environment. In addition, some p53 mutations, including L22Q and W23S, retain its pro-apoptotic properties, whereas other mutations, including L194F and R280K, lose this, which may augment tumorigenesis and disease progression $[51,56]$. Similarly, mutant (such as $\mathrm{R} 172 \mathrm{H}$ and $\mathrm{R} 270 \mathrm{H}$ ) and p53 deletions when combined with mutant KRAS inhibit apoptosis and promote tumor metastasis in genetic lung cancer mouse models and patients $[76,77]$. In addition, the NF- $\mathrm{kB}$ signaling pathway, which is associated with inflammation, and apoptosis, is also stimulated by mutant p53 with KRAS expression in murine lung cancer models [72,78]. Finally, mutant p53 can promote mitochondrial activity and antioxidant capacity, correlating with poor clinical outcomes $[79,80]$.

\section{3. $p 53$ and Smoking}

Smoking is the number one risk factor of lung cancer incidence. In the United States and European Union, about $90 \%$ of males and $75 \%$ of females diagnosed with lung cancer are smokers [80-82]. Genetic research shows tobacco-associated cancer patients have a higher frequency of p53 mutations compared with the tobacco-free patients ( $26 \%-71 \%$ compared to $8 \%-47 \%)$ [83]. Furthermore, mutant p53 is highly correlated with aggressive disease and shorter survival, indicating mutant p53 loses its tumor-suppressor role [84-87].

Genetic screening has revealed that the transversion of G:C to T:A is a characteristic hotspot in tobacco-associated lung cancer [87-89]. These mutations are commonly found in tobacco-related lung cancer at codons 157, 158 and 273, but are significantly rarer in never-smokers [87,90]. Of note, the forms of mutant p53 are different between smokers and never-smokers. Transversions and deletions account for $80 \%$ of p53 mutations in smoking women, whereas p53 transitions account for $80 \%$ in tobacco-free adenocarcinoma women [91]. Notably, while p53 mutations are often found in smokers, EGFR mutations are more frequent in females and never-smokers with adenocarcinoma. Around $15 \%$ of males and $50 \%$ of females with lung cancer are never-smokers [71,92]. Accordingly, different therapeutics must be developed that are tailored to the different p53 mutant subtypes. In addition, mutant epidermal growth factor receptor (EGFR) makes up $10 \%-40 \%$ in adenocarcinoma. EGFR abnormalities act through the PI3K/AKT/mTOR (phosphoinositide 3-kinase/protein kinase $\mathrm{B} /$ mammalian target of rapamycin) and Raf/MEK/ERK (raf/mitogen-activated protein kinase kinase/extracellular signal-regulated kinases) pathways to drive oncogenesis and are discussed below. 


\subsection{Compounds Targeting $p 53$ in NSCLC}

Exploring new compounds that target mutant p53 and restore its wild-type function are potential therapeutic strategies for cancers, especially NSCLC, due to the high mutation rate of p53 $[55,93,94]$. Several compounds have been shown such therapeutic potential. Nutlin, for example, is a compound capable of increasing wild-type p53's anti-tumor activity by blocking the interaction between p53 and MDM2 in vivo (E3 ubiquitin ligase of p53) [95]. Mammalian cell lines and mouse xenograft models show that PRIMA (p53 reactivation and induction of massive apoptosis), identified over 10 years ago, can bind to and convert mutant p53 to its wild-type structure, leading to growth inhibition and apoptosis [96,97]. RETRA (reactivation of transcriptional reporter activity) is another compound which inhibits mutant p53 activity by releasing p73 (p53 family protein with a high level of sequence similarity) from the p53 complex and activating target proteins associated with growth inhibition and apoptosis induction [98]. Hence, developing and discovering new molecules targeting abnormal p53 or promoting the pro-apoptotic role of wild-type p53 can aid clinical cancer therapy. Most p53 mutations occur at the DNA-binding domain (DBD), resulting in loss of DNA binding activity and transactivation function. Hence, restoring and stabilizing the DBD structure is also a promising strategy to restore wild-type p53's tumor-suppressor function.

\section{Mammalian Target of Rapamycin (mTOR) Pathway}

The mammalian target of rapamycin (mTOR) signal transduction pathway is involved in a variety of cellular functions upon either intracellular or extracellular stimulation (Figure 2). Numerous alterations in genes such as KRAS, EGFR, LKB1, PTEN, PIK3CA (encoding the $p 110 \alpha$ catalytic subunit of PI3K), as well as AKT1 mutations, EGFR and PIK3CA amplification, and PTEN deletion, have been described in NSCLC, which lead to uncontrolled mTOR pathway signaling. Dysregulation of the mTOR pathway is more common in squamous lung carcinoma than adenocarcinoma (Table 1) $[99,100]$. Furthermore, patients carrying mutant EGFR always exhibit aberrant PI3K/AKT/mTOR activation, which causes resistance to EGFR-tyrosine kinase inhibitor (EGFR-TKI) treatment in clinic [99].

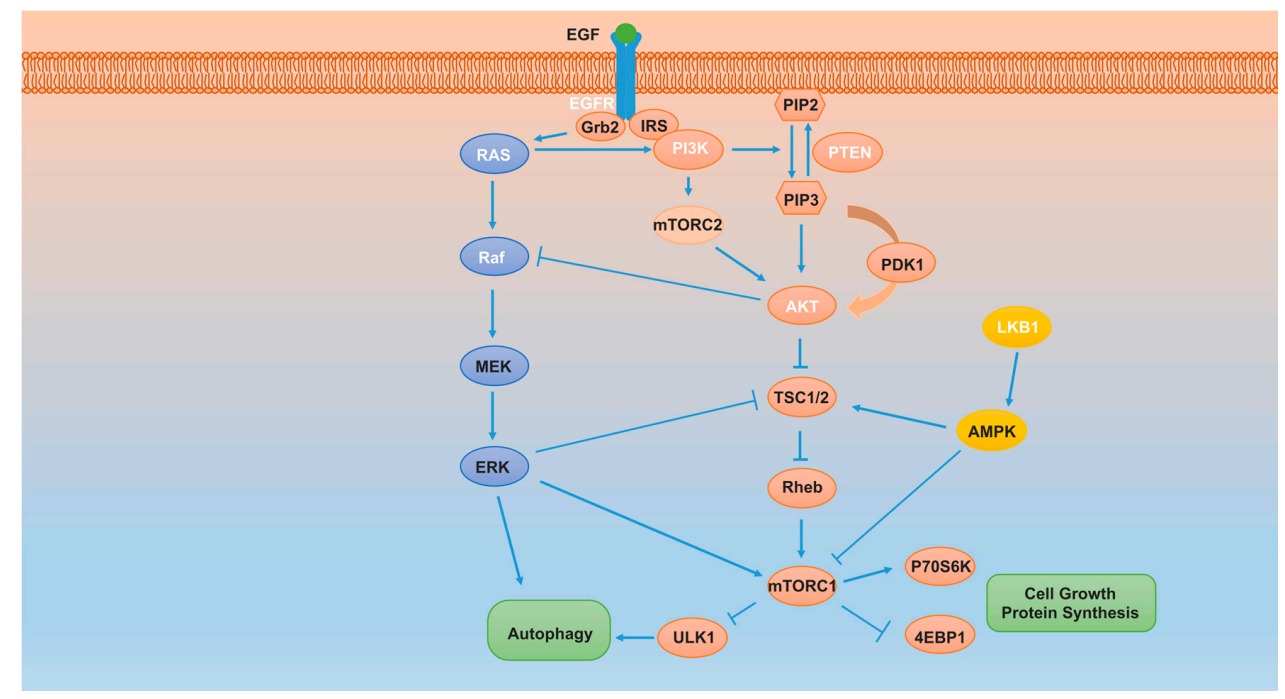

Figure 2. Overview of mammalian target of rapamycin (mTOR) pathway. The crosstalk of different pathways including (PI3K)/ (PI3K/AKT)/mTOR (phosphoinositide-3-kinase-protein/kinase B/mTOR), LKB1/AMPK/mTOR (serine/threonine kinase 11/ AMP-activated protein kinase/mTOR) and Raf/MEK/mTOR (rapidly accelerated fibrosarcoma/ mitogen-activated protein kinase kinase/mTOR) and their regulation of autophagy. Aberrant genes associated with NSCLC are marked in white. Hexagons and ovals are representative of lipids and proteins, respectively. Arrows indicate stimulation and T-bars indicate inhibition. PtdIns(3,4,5) $\mathrm{P}_{3}$ (PIP3) can activate AKT directly or recruit 3-phosphoinositide-dependent protein kinase-1 (PDK1) to phosphorylate AKT. 


\section{1. mTOR Function}

mTOR is a conserved serine/threonine kinase associated with multiple physiological functions, such as cell cycle regulation, proliferation, differentiation, motility and invasion. mTORC1 (composed of mTOR, Raptor, Deptor, mLST8 and PRAS40) and mTORC2 (made up of mTOR, Rictor, Deptor, mLST8, Sin1, and PRA5/Protor-1) are two signaling complexes involved in the mTOR pathway. Raptor and Rictor are scaffold proteins involved in mTORC1 and mTORC2 assembly, respectively. mTORC2 mediates AKT phosphorylation at Ser473 to activate mTORC1. Alternatively, activated mTORC1 sensitizes ribosomal protein S6 kinase (S6K), which in turn stimulates the mTORC2 complex. In addition, mTORC1 is energy and stress sensitive and robustly inhibited by rapamycin whereas mTORC2's insensitivity to rapamycin and nutrients due to the existence of Rictor [101]. However, prolonged and chronic rapamycin treatment will eventually suppress mTORC2 activity [102].

Numerous studies show that an important function of mTORC1 is the negative regulator of autophagy $[99,103]$. In normal and nutrient-rich conditions, mTORC1 phosphorylates UNC-51-like kinase 1(ULK1) to suppress its pro-autophagic role. The pro-autophagic ATG13, which positively regulates ULK1, can be directly phosphorylated and inhibited by mTORC1 as well. In glucose or amino acid starved conditions, AMPK can directly regulate the ULK1 or VPS34-Beclin-1-ATG14 complexes to promote autophagy or indirectly inhibit mTOC1 activity and then promote ULK1-mediated phosphorylation of FIP200 and ATG13. Furthermore, ULK1 can also mediate autophagy through phosphorylation of Beclin-1 to form the VPS34-Beclin-1-ATG14 complex to activate autophagy $[99,104,105]$.

mTOR is innately considered as a pro-survival factor and acts as an inhibitor of apoptosis. Following stress, mTOR depletion inhibits cell growth and proliferation and increases autophagy and apoptosis. In contrast, cytoplasmic p53 inactivates mTOR signaling and suppresses autophagy. The induction of autophagy is normally a self-protective process that acts to counteract apoptosis. Persistent and high levels of autophagy, however, oppose this counteraction, and instead act synergistically with apoptosis to cause cell death. Since a variety of intracellular and extracellular signals, energy status, different stresses and crosstalk with other signaling pathways affect mTOR activity, combining mTOR inhibitors with pro-apoptotic or anti-autophagic molecules may be highly efficacious.

\subsection{Effect of Phosphoinositide-3-Kinase-Protein/Kinase B (PI3K/AKT) Signaling on the mTOR Pathway}

The phosphoinositide-3-kinase-protein (PI3K)/kinase B (AKT) signaling pathway was identified in the 1980s and plays an important role in many different physiological activities, such as protein synthesis, metabolism, cell cycle regulation, proliferation and apoptosis [106]. A variety of upstream signals, such as insulin-like growth factor-1 (IGF-1), human epidermal growth factor receptor (EGFR) and vascular endothelial growth factor receptors (VEGFRs) act through the PI3K-AKT pathway to regulate mTOR activity [107]. During this process, class $1 \mathrm{~A}$ PI3Ks (PI3K $\alpha, \beta$, and $\delta$ ) are stimulated by the activated receptors and interact with the intracellular domain of receptors by adapter molecules, such as insulin receptor substrate (IRS) and growth factor receptor-bound protein 2 (Grb2). PtdIns $(4,5) \mathrm{P}_{2}$ (PIP2), a membrane phospholipid component, is converted to $\operatorname{PtdIns}(3,4,5) \mathrm{P}_{3}$ (PIP3) by PI3K-mediated phosphatidylinositols (PtdIns) modification at the 3-position. Conversely, 3-phosphatase PTEN dephosphorylates PIP3 and regenerates PIP2. In addition, SHP1/2 help to generate PtdIns(3,4) $\mathrm{P}_{2}$ by dephosphorylating at the 5-position [99,108-110].

PIP3 is an important intracellular second messenger and activates targeting proteins, such as AKT and PDK1 (3-phosphoinositide-dependent protein kinase-1, a serine/threonine kinase contains PH domain). Three isoforms of AKT have been identified, AKT1 (which is ubiquitously expressed), AKT2 and AKT3 (which are highly expressed in insulin responsive tissues or the brain and testis, respectively) [111]. AKT is a serine/threonine kinase composed of an amino-terminal pleckstrin homology $(\mathrm{PH})$ domain, central catalytic domain and carboxyl-terminal regulatory domain. Newly synthesized PIP3 is anchored on the inner leaflet of the plasma membrane and directly interacts with the PH-domain of AKT. In addition, PDK1 is also recruited on the membrane and phosphorylates AKT at Thr308, which stimulates AKT activity [112]. Following the stimulation, PRAS40 and TSC2 
are directly phosphorylated and inactivated, which in turn activate mTORC1 and promote protein synthesis and proliferation via the phosphorylation of ribosomal protein S6 kinase (S6K) and eukaryotic initiation factor 4E (eIF4E)-binding protein 1 (4EBP1) [109,113]. In addition, the maximal activity of AKT can be achieved by mTOR or PDK2-mediated phosphorylation at AKT Ser473 [114,115]. In contrast, protein phosphatase 2 (PP2A) and PH Domain Containing Leucine Rich Repeat Protein Phosphatase 1/2 (PHLPP1/2) antagonize AKT phosphorylation at Thr308 or Ser473, respectively, preventing its activation [116,117].

\subsection{Effect of Liver Kinase B1/AMP-Activated Protein Kinase (LKB1/AMPK) Signaling on the mTOR Pathway}

mTOR can also be regulated in an AKT-independent manner, for example through the LKB1/AMPK pathway $[118,119]$. The mutation or deletion of LKB1, a serine/threonine master kinase, has been found in NSCLC, which may cause loss of its tumor-suppressor function and promote tumor growth via the LKB1/AMPK/mTOR pathway $[100,120,121]$. One of the direct substrates of LKB1 is AMPK (AMP-activated protein kinase), which is an intracellular energy sensor and cell homeostasis monitor [118,122]. As a heterotrimeric serine/threonine kinase, AMPK contains a catalytic $\alpha$ subunit and two, $\beta$ and $\gamma$, regulatory subunits. Following nutrient deprivation, increased intracellular AMP and decreased ATP induce AMPK activation. LKB1 is involved in this process by phosphorylation at Thr172 of $\alpha$ activating loop [119]. Activated AMPK controls several processes, such as p53 phosphorylation [123], sirtuin1 activity [124], fatty acid, cholesterol synthesis [125] and mTOR pathway regulation. AMPK can directly phosphorylate tuberous sclerosis complex 2 (TSC2) or Raptor to inhibit mTOC1 activity [118,126-128]. During this process, the small GTPase Rheb (Ras homolog enriched in brain) is the targeting protein that propagates the mTORC1 inhibition signal emitted by TSC2.

\subsection{Effect of Raf/MEK/ERK Signaling on the mTOR Pathway}

The Raf/MEK/ERK (rapidly accelerated fibrosarcoma/mitogen-activated protein kinase kinase/extracellular signal-regulated kinase) mitogen-activated protein kinase cascade is also associated with mTOR regulation, controlling cell survival, differentiation and apoptosis. Raf and RAS mutations cause constitutive activation of Raf/MEK/ERK leading to tumorigenesis [129]. RAS is a small GTPase and functions as the cyclic switch between a GDP-bound inactive and GTP-bound active form. Multiple upstream factors, such as receptor tyrosine kinases, growth factors, heterotrimeric G-proteins, integrin, serpentine receptors and cytokine receptors can activate RAS. In addition, mutations in RAS slow the transition from GTP to GDP, leading to the constantly high activity of RAS [129]. Stimulated RAS can either evoke PI3K/AKT/mTOR pathway output or recruit and elicit Raf (MAPKKK) expression at the cell membrane. Raf then phosphorylates and activates MEK (MAPKK, intermediate kinase), which subsequently phosphorylates ERK (MAPK). Activated ERK then translocates to the nucleus and induces target gene transcription and expression, leading to cell survival, proliferation, and autophagy $[30,129]$. In addition, the Raf/MEK/ERK pathway can also activate mTORC1 activity by regulating PI3K, TSC2 and mTORC1. Conversely, AKT can phosphorylate the N-terminus of Raf, inactivating the Raf/MEK/ERK axis. Furthermore, the ERK and mTORC1 pathways can regulate the same downstream targeting proteins, such as Bad, GSK3 and YB1 [129]. This crosstalk and interaction indicate combining inhibitors against both pathways may result in an improved therapeutic outcome.

\subsection{Molecules Targeting mTOR in NSCLC}

There is great potential in inhibiting the mTOR pathway for cancer therapy [99]. Rapamycin (sirolimus), isolated in 1975 and named after the island—Rapa Nui-where it was discovered [108], strongly inhibits TOR kinase activity. Moreover, its immunosuppressive property has promoted it to application in clinical trials in the hopes that it will help counteractcancer and prevent organ transplant rejection [108]. Rapamycin can activate p53-independent mitochondrial-mediated apoptosis in NSCLC 
cells, highlighting its efficacy in this subtype of lung cancer [130]. The A549 NSCLC mouse model also shows decreased tumor growth and apoptosis upon rapamycin treatment [131].

The combination of rapamycin with other anti-cancer drugs can further increase its sensitivity and efficacy when compared to single-drug treatment. The Bcl-2 inhibitor ABT-737, for example, when combined with rapamycin, promotes apoptosis and autophagy, thereby improving radiation therapy both in vitro and in xenograft lung cancer models [132]. Rapamycin also inhibits thymidylate synthase expression and, when combined with pemetrexed (a widely used drug for NSCLC treatment), both drugs inhibit NSCLC cancer cell growth in both in vitro and in vivo models [133]. Recently, the combination of rapamycin with lipophilic bisphosphonates has been shown to be highly therapeutic in KRAS-mutant lung cancers both in vitro and in vivo [134]. Lipophilic bisphosphonates block prenylation of KRAS due to inhibition of both farnesyl and geranylgeranyldiphosphate synthases, which are required for cell growth. Bisphosphonate activates autophagy initiation, although it is ultimately unsuccessful in being completed by p62 accumulation (p62, a specific target of autophagic flux). The combination of bisphosphonate with rapamycin facilitates autophagy and significantly inhibits KRAS mutation-mediated tumor growth [134]. In addition, The EGFR tyrosine kinase inhibitor (TKI) erlotinib is regularly used in treating NSCLC patients. Using p53 null H1299 and wild-type p53 A549 cell-line models, erlotinib displays less sensitivity in H1299 cells, indicating growth inhibition is partly due to p53. Combining erlotinib with rapamycin overcomes the resistance to EGFR TKIs caused by the lack of p53 in vitro. Decreased cell proliferation upon dual treatment is accompanied with mitochondrial hyperpolarization and autophagy induction [135]. In addition, it has been shown that autophagy is not fully activated in the highly EGFR-TKI-resistant cells; therefore, co-treatment with rapamycin could enhance autophagy and restore the sensitivity to EGFR-TKIs [136].

Besides rapamycin, targeting proteins upstream of mTOR have also been studied in NSCLC, such as AZD8055 (PI3K inhibitor), NVP-BEZ235 (PI3K and mTORC1 inhibitor), Perifosine (AKT inhibitor) and GSK-690693 (AKT inhibitor). AZD8055 is an ATP-competitive mTOR inhibitor with excellent selectivity against class I PI3K isoforms and other PI3K-like kinase members $[137,138]$. AZD8055 accelerates autophagosome formation and autophagy activation versus rapamycin. It also shows more robust growth inhibition and tumor regression in NSCLC xenograft models [137]. In addition, AZD8055 treatment also induces autophagy and cell death in leukemia and breast cancer $[139,140]$.

NVP-BEZ235, another PI3K inhibitor, recently entered clinical trials for breast cancer, renal cell carcinoma and prostate cancer. Inhibition of PI3K/mTOR by NVP-BEZ235 inhibits the expression of the anti-apoptotic MCL-1 and promotes activation of the pro-apoptotic Bim [141]. Accumulating evidence suggests that combining NVP-BEZ235 with other drugs targeting pro-proliferation pathways promote its cytostatic activity causing cytotoxicity and apoptosis in NSCLC. For example, its combination with the MEK inhibitor (AZD6244) induces expression of the pro-apoptotic Bim which, accordingly, enhances apoptosis. NVP-BEZ235 plus targeted STAT3 inhibition significantly sensitizes NSCLC cells to apoptosis, which is achieved via increased CHOP (C/EBP homologous protein), which is the ER stress-targeting protein [142]. In addition, NVP-BEZ235 mediates autophagy by counteracting its pro-apoptotic role. Combining it with the autophagic inhibitor chloroquine promotes stronger growth inhibition of human lung cancer cells [143].

Perifosine (KRX-0401) is an AKT and MAPK inhibitor that induces apoptosis in NSCLC cells by downregulation of AKT and increased output of the TRAIL receptors' mediated extracellular apoptotic pathway [144]. Perifosine can also inhibit mTOR/Raptor and mTOR/Rictor assembly to reduce mTOR, Raptor, Rictor and 4EBP1 levels by tumor-suppressor FBW7, which is the ubiquitin ligase complex component. Furthermore, perifosine induces autophagy, evident by the increase of LC3. Interestingly, combining perifosine with lysosomal inhibitors enhances its anti-cancer effect [145,146], similar to the anti-apoptotic role of autophagy when treated with NVP-BEZ235. In addition, GSK-690693, an AKT kinase inhibitor, induces apoptosis in NSCLC cells accompanied by cytoprotective autophagy as well [147]. Moreover, multiple clinical trials of NSCLC, which target the mTOR pathway, are also in progress. For example, ABBV-221 (target EGFR), Navitoclax (target Bcl-2, Bcl-x and Bcl-w), Selumetinib (target Raf/MEK/ERK) and INK128 (target TORC1/2) are in phase 1 NSCLC clinical trials [148]. 


\section{Endoplasmic Reticulum (ER) Stress}

\subsection{The Mechanism of ER Stress}

The endoplasmic reticulum (ER) is the principal organelle required for protein folding, translocation modification, calcium homeostasis and lipid biosynthesis [149]. A variety of cellular stresses, such as oxidants, glucose deprivation, abnormal calcium regulation (e.g., ER-cytoplasm calcium release), viral infection, hypoxia, high-fat diet and biochemical reagents, disturb cell homeostasis and result in unfolded or misfolded protein accumulation in the ER, leading to the activation of the unfolded protein response (UPR), causing cells to rapidly adapt by speeding up the process of protein folding and limiting new protein synthesis [149-151]. Persistent and high levels of cellular stress, however, induce apoptosis, degrading the damaged cells. Both intrinsic and extrinsic apoptotic pathways and autophagy are elicited by ER stress.

There are three conserved ER transmembrane branches involved in signaling ER stress, including inositol-requiring enzyme $1 \alpha$ (IRE1 $\alpha$ ), activating transcription factor 6 (ATF6) and pancreatic ER kinase-like ER kinase (PERK) (Figure 3) [150]. The binding immunoglobulin protein (BiP) (also called GRP78 or Kar2p) is a chaperone protein that binds with the luminal domains of the transducers IRE1 $\alpha$, ATF6, and PERK under normal conditions. In ER-stressed cells, BiP disassociates from these transducers and binds with the unfolded or misfolded proteins that accumulate in the lumen to assist in protein refolding and to restore cell homeostasis. Consequently, BiP-disassociated IRE1 $\alpha$ is phosphorylated causing homo-dimerization and subsequent activation of its kinase and RNase activities that cytoplasmically splice XBP1 mRNA, thereby activating it. Newly synthesized XBP1 then translocates to the nucleus and induces gene expression of factors associated with chaperones and ER-associated protein degradation (ERAD). Similarly, released ATF6 moves to the Golgi compartment and is cleaved by the proteases sphingosine-1-phosphate (S1P) and sphingosine-2-phosphate (S2P) yielding the activated form of ATF6 that regulates target gene transcription and expression. Finally, following disassociation with BiP, PERK forms homodimers, is auto-phosphorylated and subsequently phosphorylates eIF $2 \alpha$, inhibiting the initiation of translation for most mRNAs, but activating ATF4 mRNA translation via a uORF-dependent mechanism [152]. ATF4 then translocates to the nucleus and functions as a transcription factor to stimulate anti-oxidative and apoptotic protein expression. The activation of ER stress can also elicit extrinsic apoptosis pathway activation, for example, through the induction of the death receptor 5 (DR5). Interestingly, DR5 is involved in the control of ER stress-mediated apoptosis as well [39,153-155].

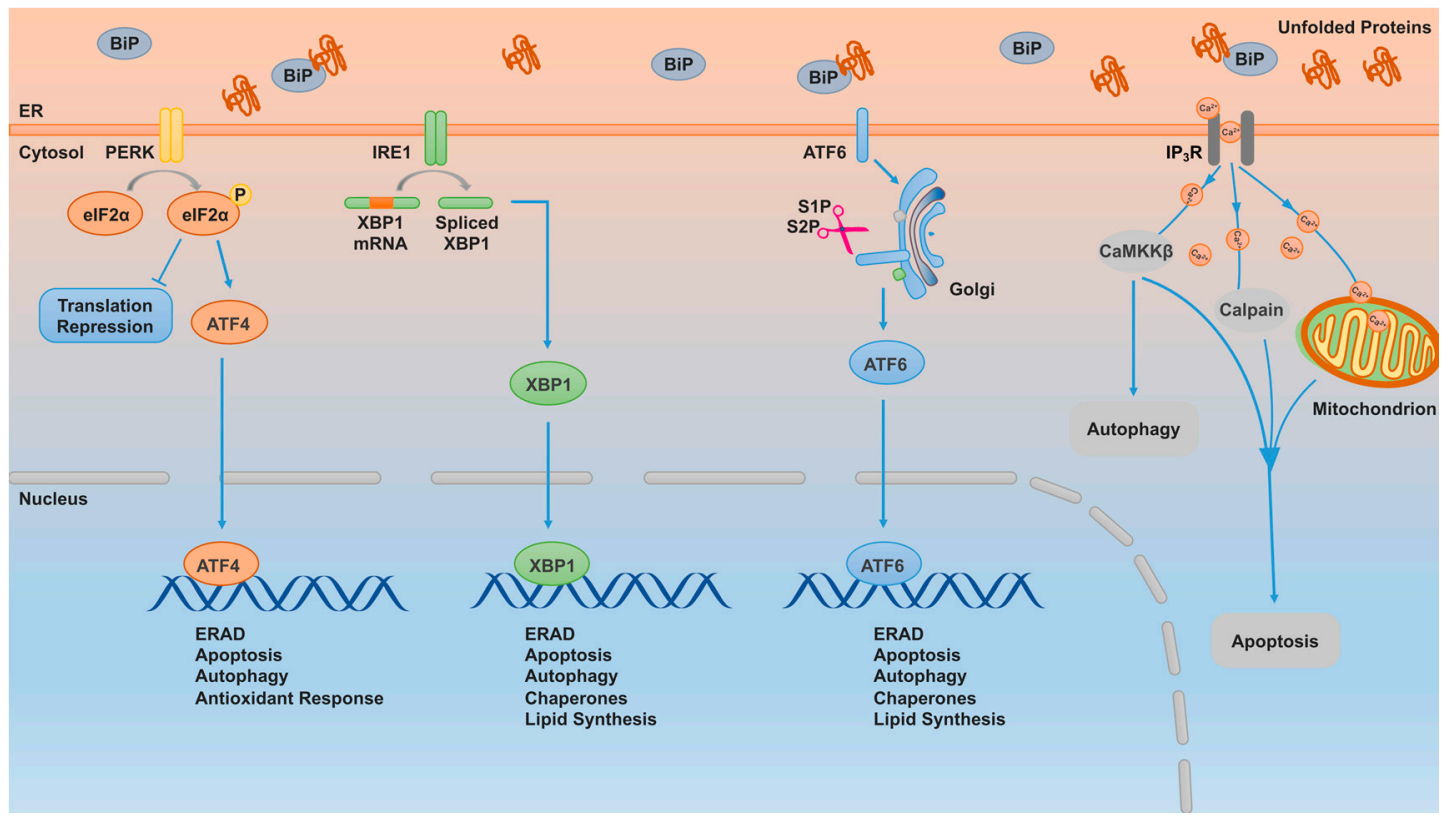

Figure 3. ER stress mediates apoptosis and autophagy. 
The ER is also involved in intracellular $\mathrm{Ca}^{2+}$ homeostasis. Following ER stress, calcium is released from the lumen to the cytosol through $\mathrm{Ca}^{2+}$ channels, such as Inositol trisphosphate receptor (IP3R). Increased cytoplasmic calcium promotes calpain expression, which is a ubiquitously expressed cysteine protease. Calpain then acts through the caspase- $4 /$ caspase- $9 /$ caspase- 3 axis to induce apoptosis. In addition, cytoplasmic calcium increases the mitochondrial calcium concentration and causes abnormal mitochondrial membrane potential. Furthermore, the released calcium elicits CaMKK $\beta$ (Calcium/calmodulin-dependent protein kinase) expression, which activates the AMPK/mTOR pathway resulting in autophagy and apoptosis [156].

\subsection{Autophagy, Apoptosis and ER Stress in NSCLC}

Several studies show that ER stress is a crucial regulator of apoptosis and autophagy. For example, curcumin, a phenolic compound isolated from the plant Curcuma longa and one of the most promising anti-cancer agents, induces apoptosis and cell cycle arrest through ER stress in A549 and H460 cells [157-159]. In addition, curcumin treatment elicits autophagy in lung adenocarcinoma A549 cells which has a pro-death effect alongside apoptosis [160]. Two ER stress proteins, CHOP and $\mathrm{BiP}$, are stimulated upon curcumin treatment. Curcumin also stimulates ER calcium release into the cytoplasm, resulting in changes in mitochondrial membrane potential, which releases cytochrome $c$ and endonuclease $G$ (endo G), which could promote caspase cascade activation or nuclear DNA degradation. Curcumin can also directly activate the Fas-mediated extracellular apoptotic pathway to induce apoptosis $[157,158]$. In addition, CLEFMA is a synthetic curcumin mimic and induces autophagy in H441 cells, as well [161].

Salinomycin, an extracted potassium ionophore from Streptomyces aibus, promotes the ATF4-DDIT3/CHOP-TRIB3 axis and suppresses AKT1 and mTOR activity, activating autophagy and apoptosis in NSCLC cells. Inhibition of autophagy by knockdown of ATG5 or ATG7 enhances salinomycin-mediated apoptosis, indicating their autophagic cytoprotective roles [162]. Similarly, H1, a bromized derivative of tetrandrine, induces ER-stress-mediated DR5 expression and apoptosis in NSCLC cells. Simultaneously, autophagy is stimulated and functions as anti-apoptotic during this process [163]. Cytoprotective autophagy in NSCLC cells has also been described upon treatment with other molecules, such as cucurbitacin E and glycerrhetinic acid [164,165].

In contrast, methyl jasmonate, a botanical hormone, causes ER stress activation and pro-apoptotic autophagy in NSCLC cells. Cryptotanshinone or isocryptotanshinone treatment in NSCLC cells also induce pro-apoptotic autophagy [13]. It is important to note that the induction of autophagy may neither be pro- nor anti-apoptotic. Licochalcone A, a flavonoid extracted from Chinese medicinal herb Glycyrrhiza uralensis Fisch, induces ER stress-mediated apoptosis and autophagy; however, the autophagic effect neither promotes nor inhibits apoptosis in NSCLC cells [166]. Together, the anti-, pro- or non-apoptotic role of autophagy is dependent upon different molecules. These mechanisms are still poorly understood and warrant further investigation.

\section{Therapeutic Approaches in NSCLC}

NSCLC is the most common cancer worldwide and is characterized by high resistance to chemoand radiation therapy, resulting in a high mortality rate. The success of immune checkpoint blockade in the clinic has encouraged the rapid development of cancer immunotherapeutics $[167,168]$. Here we will briefly talk about promising immunotherapy approaches, and briefly highlight promising Chinese medicinal approaches.

\subsection{Immunotherapy in NSCLC}

Recently, immunotherapy that stimulates the immune response and inhibits tumor growth has attracted significant attention, and opened another door in the fight against cancer, including NSCLC. In this process, tumor cells are recognized by the immune system, leading to not only tumor removal, but also restoration of the surveillance ability of immune system, which is typically suppressed during cancer development. Immune checkpoints are regulators that play an important 
role in preventing autoimmunity, detrimental inflammation and maintaining self-tolerance. In the carcinogenesis process, immune checkpoints are co-opted by tumors, resulting in immune tolerance and malignant development [169]. Hence, blocking immune checkpoints in cancer cells provides new immunotherapeutic targets.

PD-1 (programmed death receptor 1) and CTLA-4 (cytotoxic T-lymphocyte antigen 4) are two well-characterized checkpoints in NSCLC clinical trials. Normally, PD-1 inhibition is found at the site of the tumor, whereas CTLA-4 occurs primarily in the lymphoid organs [170]. Newer inhibitors have been developed to NSCLC. Nivolumab and pembrolizumab, two PD-1 antagonist antibodies, have been approved by the FDA (Food and Drug Administration) to treat NSCLC patients. Similarly, Atezolizumab, a PD-L1 (programmed death-ligand 1) antagonist antibody, is also FDA approved for NSCLC patients. Ipilimumab, a monoclonal antibody targeting CTLA-4, approved by the FDA in 2011 to treat melanoma patients, is also in phase III trials for NSCLC treatment [167-170]. Combinatorial antibody and chemo-/radiotherapy approaches are also in phase III clinical trials [171]. In summary, immunotherapy shows considerable promise in the treatment of NSCLC.

Recent studies indicate that autophagy is involved in the innate and adaptive immune response [168]. Autophagy can be stimulated by the innate immune receptors, such as TLRs (Toll-like receptors) and NLRs (nucleotide oligomerization domain (NOD)-like receptors). For example, TLR2 activates JNK and ERK signaling, which in turn stimulate phagocytosis and autophagy, enhancing the host innate immune response [172,173]. In addition, autophagy plays a role in the adaptive immune response, such as antigen presentation and development of lymphocytes ( $\mathrm{T}$ cells and B cells). Deletion of Atg 5 causes not only impaired autophagy, but also lead to defective T cell homeostasis and $\mathrm{B}$ cell development $[174,175]$. Furthermore, autophagy can play both pro-survival and pro-death roles in the context of different immunotherapy compounds [168]. How this occurs is poorly understood, and thus a key area of future study.

\subsection{Effects of Chinese Medicine on NSCLC}

Some traditional Chinese medicines target pathways implicated in cancer progression and survival, including NSCLC, liver cancer, stomach cancer and breast cancer [176]. Several Chinese medicinal compounds cause ER stress induction, which in turn induces autophagy and apoptosis, similar to the actions of curcumin, Licochalcone A and H1 mentioned above. For example, pachymic acid (also called fuling, a lanostane-type triterpenoid from Poria cocos) induces G2/M cell cycle arrest in $\mathrm{H} 23$ and H460 NSCLC cells by increasing reactive oxygen species (ROS), activating c-Jun $\mathrm{N}$-terminal kinase (JNK) and stimulating ER stress [177]. Furanodiene is a natural terpenoid isolated from Curcumae Rhizoma, which inhibits cell proliferation and induces apoptosis in 95D, A549 and H1299 NSCLC cells via stimulated ER stress evident by increased BiP and CHOP expression [178]. In addition, Platycodin-D, a triterpene saponin extracted from the root of platycodon grandiflorum, induces autophagy in both H460 and A549 NSCLC cells exhibited by up-regulation of ATG3, ATG7, Beclin-1 and LC3-II, indicating the autophagic regulation effect of Chinese medicine [179].

\section{Conclusions and Perspectives}

As the most commonly diagnosed and the leading cause of cancer-induced death, non-small-cell lung cancer (NSCLC) remains difficult to cure, with a five-year overall survival rate of around $20 \%$ despite various treatment options, including surgical resection, chemotherapy, radiotherapy and targeting therapy. Determining the molecular mechanisms of NSCLC and the discovery of new biomarkers will aid in the development of better, more specific therapeutics.

Several gene aberrations are associated with NSCLC, promoting oncogenesis and disturbing cellular homeostasis. These genes affect not only their own functions, but have a more widespread effect due to their abnormal activity, feedback loops and crosstalk between different signaling pathways, meaning that single agents may be insufficient to effectively inhibit tumor growth. Instead, co-treatments may achieve better curative effects in the clinic. 
Apoptosis and autophagy are two important physiological activities that control cell survival and cell death. The crosstalk between autophagy and apoptosis influences cell homeostasis, cargo clearance of dying cells, as well as clinical therapeutics. In this review, we summarized the most investigated factors and signaling pathways associated with autophagy and apoptosis in NSCLC, including abnormal genomes, aberrant mTOR pathway and ER stress. Further uncovering the precise nature of this elaborate and highly complicated crosstalk will have broad pathophysiological implications.

The relationship between autophagy and apoptosis is controversial and highly dependent on the context and the specific molecules that are used for treatment. In some circumstances, autophagy counteracts apoptosis, whereas in other situations, autophagy acts synergistically with apoptosis. Appropriate application of stress could theoretically tip the balance in favor of more effective cancer therapeutics, wherein transient and low doses of stress could induce autophagy, inhibit apoptosis and mediate cellular homeostasis, whereas persistent and high doses of stress might induce apoptosis. Alternatively, switch proteins or complexes may act as "guardians" that evaluate the cellular context and ultimately define which role autophagy will play during apoptosis. The apoptotic effect elicited by autophagic proteins, as well as the autophagic effect by apoptotic proteins has been discussed, highlighting the crosstalk between both processes. The use of various methods and techniques, such as co-immunoprecipitations and mass spectrometry, will help further our understanding on the crosstalk between autophagy and apoptosis and help further our understanding on how best to target these processes to treat cancers like NSCLC.

Acknowledgments: This work was supported by University of Arizona, the United States.

Author Contributions: Guangbo Liu wrote the paper; Guangbo Liu, Fen Pei, Fengqing Yang collected the data and references; Guangbo Liu, Lingxiao Li, Amit Dipak Amin, Songnian Liu drew pictures and tables; Guangbo Liu, J. Ross Buchan, William C. Cho supervised the project and revised the manuscript.

Conflicts of Interest: The authors declare no conflict of interest.

$\begin{array}{ll}\text { Abbreviations } & \\ \text { NSCLC } & \text { Non-small-cell lung cancer } \\ \text { SCLC } & \text { Small-cell lung cancer } \\ \text { mTOR } & \text { mammalian target of rapamycin } \\ \text { mTORC1 } & \text { mTOR complex 1 } \\ \text { mTORC2 } & \text { mTOR complex 2 } \\ \text { BID } & \text { BH3 interacting-domain death agonist } \\ \text { Bik } & \text { Bcl-2-interacting killer } \\ \text { Noxa } & \text { Phorbol-12-myristate-13-acetate-induced protein 1 } \\ \text { HRK } & \text { Activator of apoptosis harakiri } \\ \text { PUMA } & \text { BCL2 Binding Component 3 } \\ \text { Bax } & \text { BCL2 Associated X } \\ \text { Bak } & \text { Bcl-2 homologous antagonist/killer } \\ \text { Bim } & \text { BCL2-Like 11 } \\ \text { Bcl-2 } & \text { B-cell lymphoma 2 } \\ \text { Bfl-1 } & \text { BCL2 Related Protein A1 } \\ \text { MCL-1 } & \text { Myeloid Cell Leukemia Sequence 1 } \\ \text { Fas } & \text { Tumor Necrosis Factor Receptor Superfamily, Member 6 } \\ \text { RTK } & \text { Receptor tyrosine kinase } \\ \text { PI3K } & \text { Phosphatidylinositol-3 kinase } \\ \text { TNF } \alpha & \text { Tumor necrosis factor alpha } \\ \text { TNFR1 } & \text { TNF } \alpha \text { Receptor 1 } \\ \text { TRADD } & \text { TNFR1-associated death domain } \\ \text { TRAIL } & \text { TNF-related apoptosis inducing ligand } \\ \text { FADD } & \text { Nuclear factor kappa-light-chain-enhancer of activated B cells } \\ \text { NF- } \text { B B } & \\ & \end{array}$




$\begin{array}{ll}\text { MDM2 } & \text { Mouse double minute 2 homolog } \\ \text { MOMP } & \text { Mitochondrial outer membrane permeabilization } \\ \text { ER stress } & \text { Endoplasmic reticulum stress } \\ \text { DISC } & \text { Death-inducing signaling complex } \\ \text { FIP200 } & \text { FAK family kinase-interacting protein of 200 kDa } \\ \text { ULK1 } & \text { UNC-51-like kinase 1 } \\ \text { IGF-1 } & \text { Insulin-like growth factor-1 } \\ \text { HER } & \text { Human epidermal growth factor receptor } \\ \text { VEGFRs } & \text { Vascular endothelial growth factor receptors } \\ \text { IRS } & \text { Insulin receptor substrate } \\ \text { PtdIns }(4,5) P_{2} & \text { Phosphatidylinositol 4,5-bisphosphate } \\ \text { PtdIns(3,4,5)P } & \text { Phosphatidylinositol (3,4,5)-trisphosphate } \\ \text { PtdIns }(3,4) P_{2} & \text { Phosphatidylinositol 3,4-bisphosphate } \\ \text { PTEN } & \text { Phosphatase and tensin homolog } \\ \text { PDK1 } & \text { 3-Phosphoinositide-dependent protein kinase-1 } \\ \text { PP2A } & \text { Protein phosphatase 2 } \\ \text { LKB1 } & \text { Liver kinase B1 } \\ \text { ERAD } & \text { Endoplasmic-reticulum-associated protein degradation }\end{array}$

\section{References}

1. Siegel, R.L.; Miller, K.D.; Jemal, A. Cancer statistics. CA Cancer J. Clin. 2016, 66, 7-30. [CrossRef] [PubMed]

2. Neal, R.D.; Hamilton, W.; Rogers, T.K. Lung cancer. BMJ 2014, 349, g6560. [CrossRef] [PubMed]

3. Levine, B.; Kroemer, G. Autophagy in the Pathogenesis of Disease. Cell 2008, 132, 27-42. [CrossRef] [PubMed]

4. Maiuri, M.C.; Zalckvar, E.; Kimchi, A.; Kroemer, G. Self-eating and self-killing: Crosstalk between autophagy and apoptosis. Nat. Rev. Mol. Cell Biol. 2007, 8, 741-752. [CrossRef] [PubMed]

5. Galluzzi, L.; Pietrocola, F.; Bravo-San Pedro, J.M.; Amaravadi, R.K.; Baehrecke, E.H.; Cecconi, F.; Codogno, P.; Debnath, J.; Gewirtz, D.A.; Karantza, V.; et al. Autophagy in malignant transformation and cancer progression. EMBO J. 2015, 34, 856-880. [CrossRef] [PubMed]

6. Kerr, J.F.R.; Wyllie, A.H.; Currie, A.R. Apoptosis: A basic biological phenomenon with wide-ranging implications in tissue kinetics. Br. J. Cancer 1972, 26, 239-257. [CrossRef] [PubMed]

7. Marino, G.; Niso-Santano, M.; Baehrecke, E.H.; Kroemer, G. Self-consumption: The interplay of autophagy and apoptosis. Nat. Rev. Mol. Cell Biol. 2014, 15, 81-94. [CrossRef] [PubMed]

8. Horvitz, H.R. Genetic control of programmed cell death in the nematode Caenorhabditis elegans. Cancer Res. 1999, 59, 1701S-1706S. [PubMed]

9. Lindsten, T.; Ross, A.J.; King, A.; Zong, W.X.; Rathmell, J.C.; Shiels, H.A.; Ulrich, E.; Waymire, K.G.; Mahar, P.; Frauwirth, K.; et al. The combined functions of proapoptotic Bcl-2 family members Bak and Bax are essential for normal development of multiple tissues. Mol. Cell 2000, 6, 1389-1399. [CrossRef]

10. Fuchs, Y.; Steller, H. Programmed cell death in animal development and disease. Cell 2014, 147, 742-758. [CrossRef] [PubMed]

11. Kroemer, G.; Mariño, G.; Levine, B. Autophagy and the Integrated Stress Response. Mol. Cell 2010, 40, 280-293. [CrossRef] [PubMed]

12. Dang, S.; Yu, Z.M.; Zhang, C.Y.; Zheng, J.; Li, K.L.; Wu, Y.; Qian, L.L.; Yang, Z.Y.; Li, X.R.; Zhang, Y.; et al. Autophagy promotes apoptosis of mesenchymal stem cells under inflammatory microenvironment. Stem Cell Res. Ther. 2015, 15, 247. [CrossRef] [PubMed]

13. Zhang, M.; Su, L.; Xiao, Z.; Liu, X.; Liu, X. Methyl jasmonate induces apoptosis and pro-apoptotic autophagy via the ROS pathway in human non-small cell lung cancer. Am. J. Cancer Res. 2016, 6, 187-199. [PubMed]

14. Denton, D.; Shravage, B.; Simin, R.; Mills, K.; Berry, D.L.; Baehrecke, E.H.; Kumar, S. Autophagy, Not Apoptosis, Is Essential for Midgut Cell Death in Drosophila. Curr. Biol. 2009, 19, 1741-1746. [CrossRef] [PubMed]

15. Denton, D.; Nicolson, S.; Kumar, S. Cell death by autophagy: Facts and apparent artefacts. Cell Death Differ. 2012, 19, 87-95. [CrossRef] [PubMed] 
16. Liu, Y.; Shoji-Kawata, S.; Sumpter, R.M.; Wei, Y.; Ginet, V.; Zhang, L.; Posner, B.; Tran, K.A.; Green, D.R.; Xavier, R.J.; et al. Autosis is a $\mathrm{Na}^{+}, \mathrm{K}^{+}$-ATPase-regulated form of cell death triggered by autophagy-inducing peptides, starvation, and hypoxia-ischemia. Proc. Natl. Acad. Sci. USA 2013, 110, 20364-20371. [CrossRef] [PubMed]

17. Galluzzi, L.; Bravo-San Pedro, J.M.; Vitale, I.; Aaronson, S.A.; Abrams, J.M.; Adam, D.; Alnemri, E.S.; Altucci, L.; Andrews, D.; Annicchiarico-Petruzzelli, M.; et al. Essential versus accessory aspects of cell death: Recommendations of the NCCD 2015. Cell Death Differ. 2015, 22, 58-73. [CrossRef] [PubMed]

18. White, E. The role for autophagy in cancer. J. Clin. Investig. 2015, 125, 42-46. [CrossRef]

19. Ye, M.X.; Li, Y.; Yin, H.; Zhang, J. Curcumin: Updated molecular mechanisms and intervention targets in human lung cancer. Int. J. Mol. Sci. 2012, 13, 3959-3978. [CrossRef] [PubMed]

20. Hamasaki, M.; Furuta, N.; Matsuda, A.; Nezu, A.; Yamamoto, A.; Fujita, N.; Oomori, H.; Noda, T.; Haraguchi, T.; Hiraoka, Y.; et al. Autophagosomes form at ER-mitochondria contact sites. Nature 2013, 495, 389-393. [CrossRef] [PubMed]

21. Choi, A.M.K.; Ryter, S.W.; Levine, B. Autophagy in human health and disease. N. Engl. J. Med. 2013, 368, 1845-1846. [CrossRef] [PubMed]

22. Russell, R.C.; Yuan, H.-X.; Guan, K.-L. Autophagy regulation by nutrient signaling. Cell Res. 2014, $24,42-57$. [CrossRef] [PubMed]

23. Mizushima, N.; Komatsu, M. Autophagy: Renovation of cells and tissues. Cell 2011, 147, 728-741. [CrossRef] [PubMed]

24. Thumm, M.; Egner, R.; Koch, B.; Schlumpberger, M.; Straub, M.; Veenhuis, M.; Wolf, D.H. Isolation of autophagocytosis mutants of Saccharomyces cerevisiae. FEBS Lett. 1994, 349, 275-280. [CrossRef]

25. Mizushima, N.; Noda, T.; Yoshimori, T.; Tanaka, Y.; Ishii, T.; George, M.D.; Klionsky, D.J.; Ohsumi, M.; Ohsumi, Y. A protein conjugation system essential for autophagy. Nature 1998, 395, 395-398. [PubMed]

26. Klionsky, D.J.; Abdelmohsen, K.; Abe, A.; Abedin, M.J.; Abeliovich, H.; Acevedo Arozena, A.; Adachi, H.; Adams, C.M.; Adams, P.D.; Adeli, K.; et al. Guidelines for use and interpretation of assays for monitoring autophagy (3rd edition). Autophagy 2016, 12, 1-222. [PubMed]

27. Hirsch, T.; Xiang, J.; Chao, D.T.; Korsmeyer, S.J.; Scaife, J.F.; Colell, A.; Morales, A.; Ferna, J.C.; Adachi, S.; Cross, A.R.; et al. Caspases: Enemies Within. Science 1998, 281, 1312-1316.

28. Hengartner, M.O. The biochemistry of apoptosis. Nature 2000, 407, 770-776. [CrossRef] [PubMed]

29. Martinon, F.; Tschopp, J. Inflammatory caspases: Linking an intracellular innate immune system to autoinflammatory diseases. Cell 2004, 117, 561-574. [CrossRef] [PubMed]

30. Li, H.; Zhu, H.; Xu, C.J.; Yuan, J.Y. Cleavage of BID by Caspase 8 Mediates the Mitochondrial Damage in the Fas Pathway of Apoptosis. Cell 1998, 21, 491-501. [CrossRef]

31. Zou, H.; Li, Y.; Liu, X.; Wang, X. An APAf-1 cytochrome C multimeric complex is a functional apoptosome that activates procaspase-9. J. Biol. Chem. 1999, 274, 11549-11556. [CrossRef] [PubMed]

32. Hata, A.N.; Engelman, J.A.; Faber, A.C. The BCL2 family: Key mediators of the apoptotic response to targeted anticancer therapeutics. Cancer Discov. 2015, 5, 475-487. [CrossRef] [PubMed]

33. Delbridge, A.R.D.; Strasser, A. The BCL-2 protein family, BH3-mimetics and cancer therapy. Cell Death Differ. 2015, 22, 1071-1080. [CrossRef] [PubMed]

34. Beroukhim, R.; Mermel, C.H.; Porter, D.; Wei, G.; Raychaudhuri, S.; Donovan, J.; Barretina, J.; Boehm, J.S.; Dobson, J.; Urashima, M.; et al. The landscape of somatic copy-number alteration across human cancers. Nature 2010, 463, 899-905. [CrossRef] [PubMed]

35. Li, M.; Gao, P.; Zhang, J. Crosstalk between autophagy and apoptosis: Potential and emerging therapeutic targets for cardiac diseases. Int. J. Mol. Sci. 2016, 17, 1-19. [CrossRef] [PubMed]

36. Wei, Y.; Pattingre, S.; Sinha, S.; Bassik, M.; Levin, B. JNK1-Mediated Phosphorylation of Bcl-2 Regulates Starvation-Induced Autophagy. Mol. Cell 2008, 20, 678-688. [CrossRef] [PubMed]

37. Wei, Y.; Sinha, S.; Levine, B. Dual role of JNK1-mediated phosphorylation of Bcl-2 in autophagy and apoptosis regulation. Autophagy 2008, 4, 949-951. [CrossRef] [PubMed]

38. Trenti, A.; Grumati, P.; Cusinato, F.; Orso, G.; Bonaldo, P.; Trevisi, L. Cardiac glycoside ouabain induces autophagic cell death in non-small cell lung cancer cells via a JNK-dependent decrease of Bcl-2. Biochem. Pharmacol. 2014, 89, 197-209. [CrossRef] [PubMed] 
39. Su, L.; Liu, G.; Hao, X.; Zhong, N.; Zhong, D.; Liu, X.; Singhal, S. Death Receptor 5 and cellular FLICE-inhibitory protein regulate pemetrexed-induced apoptosis in human lung cancer cells. Eur. J. Cancer 2011, 47, 2471-2478. [CrossRef] [PubMed]

40. Lee, J.-S.; Li, Q.; Lee, J.-Y.; Lee, S.-H.; Jeong, J.H.; Lee, H.-R.; Chang, H.; Zhou, F.-C.; Gao, S.-J.; Liang, C.; et al. FLIP-mediated autophagy regulation in cell death control. Nat. Cell Biol. 2009, 11, 1355-1362. [PubMed]

41. Han, J.; Hou, W.; Goldstein, L.A.; Stolz, D.B.; Watkins, S.C.; Rabinowich, H. A Complex between Atg7 and Caspase-9: A Novel Mechanism of Cross-Regulation between Autophagy and Apoptosis. J. Biol. Chem. 2014, 289, 6485-6497. [CrossRef] [PubMed]

42. Betin, V.M.S.; Lane, J.D. Atg4D at the interface between autophagy and apoptosis. Autophagy 2009, 5, 1057-1059. [CrossRef] [PubMed]

43. Radoshevich, L.; Murrow, L.; Chen, N.; Fernandez, E.; Roy, S.; Fung, C.; Debnath, J. ATG12 conjugation to ATG3 regulates mitochondrial homeostasis and cell death. Cell 2010, 142, 590-600. [CrossRef] [PubMed]

44. Bento, C.F.; Renna, M.; Ghislat, G.; Puri, C.; Ashkenazi, A.; Vicinanza, M.; Menzies, F.M.; Rubinsztein, D.C. Mammalian Autophagy: How Does It Work? Annu. Rev. Biochem. 2016, 85, 685-713. [CrossRef] [PubMed]

45. Yousefi, S.; Perozzo, R.; Schmid, I.; Ziemiecki, A.; Schaffner, T.; Scapozza, L.; Brunner, T.; Simon, H.-U. Calpain-mediated cleavage of Atg5 switches autophagy to apoptosis. Nat. Cell Biol. 2006, 8, 1124-1132. [CrossRef] [PubMed]

46. Rubinstein, A.D.; Eisenstein, M.; Ber, Y.; Bialik, S.; Kimchi, A. The autophagy protein atg12 associates with antiapoptotic Bcl-2 family members to promote mitochondrial apoptosis. Mol. Cell 2011, 44, 698-709. [CrossRef] [PubMed]

47. Wu, H.; Che, X.; Zheng, Q.; Wu, A.; Pan, K.; Shao, A.; Wu, Q.; Zhang, J.; Hong, Y. Caspases: A molecular switch node in the crosstalk between autophagy and apoptosis. Int. J. Biol. Sci. 2014, 10, 1072-1083. [CrossRef] [PubMed]

48. Oral, O.; Oz-Arslan, D.; Itah, Z.; Naghavi, A.; Deveci, R.; Karacali, S.; Gozuacik, D. Cleavage of Atg3 protein by caspase-8 regulates autophagy during receptor-activated cell death. Apoptosis 2012, 17, 810-820. [CrossRef] [PubMed]

49. Wirawan, E.; Vande Walle, L.; Kersse, K.; Cornelis, S.; Claerhout, S.; Vanoverberghe, I.; Roelandt, R.; de Rycke, R.; Verspurten, J.; Declercq, W.; et al. Caspase-mediated cleavage of Beclin-1 inactivates Beclin-1-induced autophagy and enhances apoptosis by promoting the release of proapoptotic factors from mitochondria. Cell Death Dis. 2010, 1, e18. [CrossRef] [PubMed]

50. Carper, M.B.; Claudio, P.P. Clinical potential of gene mutations in lung cancer. Clin. Transl. Med. 2015, 4, 33. [CrossRef] [PubMed]

51. Kruse, J.P.; Gu, W. Modes of p53 Regulation. Cell 2009, 137, 609-622. [CrossRef] [PubMed]

52. Vousden, K.H.; Lane, D.P. P53 in Health and Disease. Nat. Rev. Mol. Cell Biol. 2007, 8, 275-283. [CrossRef] [PubMed]

53. Green, D.R.; Kroemer, G. Cytoplasmic functions of the tumour suppressor p53. Nature 2009, 458, 1127-1130. [CrossRef] [PubMed]

54. Vaseva, A.V.; Marchenko, N.D.; Ji, K.; Tsirka, S.E.; Holzmann, S.; Moll, U.M. P53 opens the mitochondrial permeability transition pore to trigger necrosis. Cell 2012, 149, 1536-1548. [CrossRef] [PubMed]

55. Pflaum, J.; Schlosser, S.; Müller, M. p53 Family and Cellular Stress Responses in Cancer. Front. Oncol. 2014, 4, 285.

56. Giorgi, C.; Bonora, M.; Sorrentino, G.; Missiroli, S.; Poletti, F.; Suski, J.M.; Galindo Ramirez, F.; Rizzuto, R.; Di Virgilio, F.; Zito, E.; et al. p53 at the endoplasmic reticulum regulates apoptosis in a $\mathrm{Ca}^{2+}$-dependent manner. Proc. Natl. Acad. Sci. USA 2015, 112, 2-7. [CrossRef] [PubMed]

57. Bittremieux, M.; Bultynck, G. p53 and $\mathrm{Ca}^{2+}$ signaling from the endoplasmic reticulum: Partners in anti-cancer therapies. Oncoscience 2015, 2, 233-238. [CrossRef] [PubMed]

58. Budanov, A.V.; Karin, M. p53 Target Genes Sestrin1 and Sestrin2 Connect Genotoxic Stress and mTOR Signaling. Cell 2008, 134, 451-460. [CrossRef] [PubMed]

59. Tasdemir, E.; Maiuri, M.C.; Galluzzi, L.; Vitale, I.; Djavaheri-Mergny, M.; D’Amelio, M.; Criollo, A.; Morselli, E.; Zhu, C.; Harper, F.; et al. Regulation of autophagy by cytoplasmic p53. Nat. Cell Biol. 2008, 10, 676-687. [CrossRef] [PubMed] 
60. Komarov, P.G.; Komarova, E.A.; Kondratov, R.V.; Christov-Tselkov, K.; Coon, J.S.; Chernov, M.V.; Gudkov, A.V. A chemical inhibitor of p53 that protects mice from the side effects of cancer therapy. Science 1999, 285, 1733-1737. [CrossRef] [PubMed]

61. Nikoletopoulou, V.; Markaki, M.; Palikaras, K.; Tavernarakis, N. Crosstalk between apoptosis, necrosis and autophagy. Biochim. Biophys. Acta Mol. Cell Res. 2013, 1833, 3448-3459. [CrossRef] [PubMed]

62. Hao, Q.; Cho, W.C. Battle against cancer: An everlasting saga of p53. Int. J. Mol. Sci. 2014, 15, $22109-22127$. [CrossRef] [PubMed]

63. Lane, D.P.; Crawford, L.V. T antigen is bound to a host protein in SV40-transformed cells. Nature 1979, 278, 261-263. [CrossRef] [PubMed]

64. Linzer, D.I.H.; Levine, A.J. Characterization of a 54K Dalton cellular SV40 tumor antigen present in SV40-transformed cells and uninfected embryonal carcinoma cells. Cell 1979, 17, 43-52. [CrossRef]

65. Kress, M.; May, E.; Cassingena, R.; May, P. Simian virus 40-transformed cells express new species of proteins precipitable by anti-simian virus 40 tumor serum. J. Virol. 1979, 31, 472-483. [PubMed]

66. Melero, J.; Stitt, D.T.; Mangel, W.F.; Carroll, R.B. Identification of new polypeptide species (48-55 K) immunoprecipitable by antiserum to purified large T antigen and present in SV40-infected and -transformed cells. Virology 1979, 93, 466-480. [CrossRef]

67. Chen, P.L.; Chen, Y.M.; Bookstein, R.; Lee, W.H. Genetic mechanisms of tumor suppression by the human p53 gene. Science 1990, 250, 1576-1580. [CrossRef] [PubMed]

68. Munro, A.J.; Lain, S.; Lane, D.P. P53 abnormalities and outcomes in colorectal cancer: A systematic review. Br. J. Cancer 2005, 92, 434-444. [CrossRef] [PubMed]

69. Vogelstein, B.; Lane, D.; Levine, A.J. Surfing the p53 network. Nature 2000, 408, 307-310. [CrossRef] [PubMed]

70. Muller, P.A.J.; Vousden, K.H. Mutant p53 in cancer: New functions and therapeutic opportunities. Cancer Cell 2014, 25, 304-317. [CrossRef] [PubMed]

71. Mogi, A.; Kuwano, H. TP53 mutations in nonsmall cell lung cancer. J. Biomed. Biotechnol. 2011, $2011,583929$. [CrossRef] [PubMed]

72. Muller, P.A.J.; Vousden, K.H.; Patricia, A.J.M.; Karen, H.V. P53 Mutations in Cancer. Nat. Cell Biol. 2013, 15, 2-8. [CrossRef] [PubMed]

73. Vousden, K.H.; Lu, X. Live or let die: The cell's response to p53. Nat. Rev. Cancer 2002, 2, 594-604. [CrossRef] [PubMed]

74. Eliyahu, D.; Raz, A.; Gruss, P.; Givol, D.; Oren, M. Participation of p53 cellular tumour antigen in transformation of normal embryonic cells. Nature 1984, 312, 646-649. [CrossRef] [PubMed]

75. Steels, E.; Paesmans, M.; Berghmans, T.; Branle, F.; Lemaitre, F.; Mascaux, C.; Meert, A.P.; Vallot, F.; Lafitte, J.J.; Sculier, J.P. Role of p53 as a prognostic factor for survival in lung cancer: A systematic review of the literature with a meta-analysis. Eur. Respir. J. 2001, 18, 705-719. [CrossRef] [PubMed]

76. Jackson, E.L.; Olive, K.P.; Tuveson, D.A.; Bronson, R.; Crowley, D.; Brown, M.; Jacks, T. The differential effects of mutant p53 alleles on advanced murine lung cancer. Cancer Res. 2005, 65, 10280-10288. [CrossRef] [PubMed]

77. Zheng, S.; El-Naggar, K.; Kim, E.S.; Kurie, J.M.; Lozano, G. A genetic mouse model for metastatic lung cancer with gender differences in survival. Oncogene 2007, 26, 6896-6904. [CrossRef] [PubMed]

78. Xue, W.; Meylan, E.; Oliver, T.G.; Feldser, D.M.; Winslow, M.M.; Bronson, R.; Jacks, T. Response and resistance to NF-KB inhibitors in mouse models of lung adenocarcinoma. Cancer Discov. 2011, 1, 236-247. [CrossRef] [PubMed]

79. Tan, A.S.; Baty, J.W.; Dong, L.F.; Bezawork-Geleta, A.; Endaya, B.; Goodwin, J.; Bajzikova, M.; Kovarova, J.; Peterka, M.; Yan, B.; et al. Mitochondrial genome acquisition restores respiratory function and tumorigenic potential of cancer cells without mitochondrial DNA. Cell Metab. 2015, 21, 81-94. [CrossRef] [PubMed]

80. Tyczynski, J.E.; Bray, F.; Maxwell Parkin, D. Lung cancer in Europe in 2000: Epidemiology, prevention, and early detection. Lancet Oncol. 2003, 4, 45-55. [CrossRef]

81. Tyczynski, J.E.; Bray, F.; Aareleid, T.; Dalmas, M.; Kurtinaitis, J.; Plesko, I.; Pompe-Kirn, V.; Stengrevics, A.; Parkin, D.M. Lung cancer mortality patterns in selected Central, Eastern and Southern European countries. Int. J. Cancer 2004, 109, 598-610. [CrossRef] [PubMed]

82. Tyczynski, J.E.; Berkel, H.J. Mortality from lung cancer and tobacco smoking in Ohio (U.S.): Will increasing smoking prevalence reverse current decreases in mortality? Cancer Epidemiol. Biomarkers Prev. 2005, 14, 1182-1187. [CrossRef] [PubMed] 
83. Bennett, W.P.; Michael, C.R.; Blomeke, B.; Va, H.; Welsh, J.A.; Bowman, E.D.; Khan, M.A.; Douglas, B.; Harris, C.C. Environmental Tobacco Smoke, Genetic Susceptibility, and Risk of Lung Cancer in Never-Smoking Women. J. Natl. Cancer Inst. 1999, 91, 2009-2014. [CrossRef] [PubMed]

84. Doll, R.; Peto, R. Mortality in Relation To Smoking: Ten Years' Observations of British Doctors. Br. Med. J. 1976, 2, 1525-1536. [CrossRef] [PubMed]

85. Hecht, S.S. Progress and challenges in selected areas of tobacco carcinogenesis. Chem. Res. Toxicol. 2008, 21, 160-171. [CrossRef] [PubMed]

86. Takagi, Y.; Osada, H.; Kuroishi, T.; Mitsudomi, T.; Kondo, M.; Niimi, T.; Saji, S.; Gazdar, A.F.; Takahashi, T.; Minna, J.D. p53 Mutations in Non-Small-Cell Lung Cancers Occurring in Individuals Without a Past History of Active Smoking. Br. J. Cancer 1998, 77, 1568-1572. [CrossRef] [PubMed]

87. Vähäkangas, K.H.; Bennett, W.P.; Castrén, K.; Castre, K.; Welsh, J.A.; Khan, M.A.; Alavanja, M.C.R.; Harris, C.C. p53 and K-ras Mutations in Lung Cancers from Former and Never-Smoking Women. Cancer Res. 2001, 61, 4350-4356. [PubMed]

88. Mitsudomi, T.; Hamajima, N.; Ogawa, M.; Takahashi, T. Prognostic significance of p53 alterations in patients with non-small cell lung cancer: A meta-analysis. Clin. Cancer Res. 2000, 6, 4055-4063. [PubMed]

89. Hainaut, P.; Olivier, M.; Pfeifer, G.P. TP53 mutation spectrum in lung cancers and mutagenic signature of components of tobacco smoke: Lessons from the IARC TP53 mutation database. Mutagenesis 2001, 16, 551-553. [CrossRef] [PubMed]

90. Hernandez-Boussard, T.M.; Hainaut, P. A specific spectrum of p53 mutations in lung cancer from smokers: Review of mutations compiled in the IARC p53 database. Environ. Health Perspect. 1998, 106, 385-391. [CrossRef] [PubMed]

91. Gealy, R.; Zhang, L.; Siegfried, J.M.; Luketich, J.D.; Keohavong, P. Comparison of mutations in the p53 and K-ras genes in lung carcinomas from smoking and nonsmoking women. Cancer Epidemiol. Biomark. Prev. 1999, 8, 297-302.

92. Gow, C.H.; Chang, Y.L.; Hsu, Y.C.; Tsai, M.F.; Wu, C.T.; Yu, C.J.; Yang, C.H.; Lee, Y.C.; Yang, P.C.; Shih, J.Y. Comparison of epidermal growth factor receptor mutations between primary and corresponding metastatic tumors in tyrosine kinase inhibitor-naive non-small-cell lung cancer. Ann. Oncol. 2009, 20, 696-702. [CrossRef] [PubMed]

93. Parrales, A.; Iwakuma, T. Targeting Oncogenic Mutant p53 for Cancer Therapy. Front Oncol. 2015, 5, 288. [CrossRef] [PubMed]

94. Gibbons, D.L.; Byers, L.A.; Kurie, J.M. Smoking, p53 mutation, and lung cancer. Mol. Cancer Res. 2014, 12, 3-13. [CrossRef] [PubMed]

95. Vassilev, L.T.; Vu, B.T.; Craves, B.; Carvajal, D.; Podlaski, F.; Filipovic, Z.; Kong, N.; Kammlott, U.; Lukacs, C.; Klein, C.; et al. In Vivo Activation of the p53 Pathway by Small-MoleculeAntagonists of MDM2. Science 2004, 303, 844-848. [CrossRef] [PubMed]

96. Bykov, V.J.N.; Issaeva, N.; Shilov, A.; Hultcrantz, M.; Pugacheva, E.; Chumakov, P.; Bergman, J.; Wiman, K.G.; Selivanova, G. Restoration of the tumor suppressor function to mutant p53 by a low-molecular-weight compound. Nat. Med. 2002, 8, 282-288. [CrossRef] [PubMed]

97. Lambert, J.M.R.; Gorzov, P.; Veprintsev, D.B.; Söderqvist, M.; Segerbäck, D.; Bergman, J.; Fersht, A.R.; Hainaut, P.; Wiman, K.G.; Bykov, V.J.N. PRIMA-1 Reactivates Mutant p53 by Covalent Binding to the Core Domain. Cancer Cell 2009, 15, 376-388. [CrossRef] [PubMed]

98. Kravchenko, J.E.; Ilyinskaya, G.V.; Komarov, P.G.; Agapova, L.S.; Kochetkov, D.V.; Strom, E.; Frolova, E.I.; Kovriga, I.; Gudkov, A.V.; Feinstein, E.; et al. Small-molecule RETRA suppresses mutant p53-bearing cancer cells through a p73-dependent salvage pathway. Proc. Natl. Acad. Sci. USA 2008, 105, 6302-6307. [CrossRef] [PubMed]

99. Fumarola, C.; Bonelli, M.A.; Petronini, P.G.; Alfieri, R.R. Targeting PI3K/AKT/mTOR pathway in non-small cell lung cancer. Biochem. Pharmacol. 2014, 90, 197-207. [CrossRef] [PubMed]

100. Han, D.; Li, S.; Zhu, Y.; Liu, L.; Li, M. LKB1/AMPK/mTOR Signaling Pathway in Non-small-cell Lung Cancer. Asian Pac. J. Cancer 2013, 14, 4033-4039. [CrossRef]

101. Loewith, R.; Jacinto, E.; Wullschleger, S.; Lorberg, A.; Crespo, J.L.; Bonenfant, D.; Oppliger, W.; Jenoe, P.; Hall, M.N. Two TOR complexes, only one of which is rapamycin sensitive, have distinct roles in cell growth control. Mol. Cell 2002, 10, 457-468. [CrossRef] 
102. Mendoza, M.C.; Er, E.E.; Blenis, J. The Ras-ERK and PI3K-mTOR pathways: Cross-talk and compensation. Trends Biochem. Sci. 2011, 36, 320-328. [CrossRef] [PubMed]

103. Shimobayashi, M.; Hall, M.N. Making new contacts: The mTOR network in metabolism and signalling crosstalk. Nat. Rev. Mol. Cell Biol. 2014, 15, 155-162. [CrossRef] [PubMed]

104. Randall-Demllo, S.; Chieppa, M.; Eri, R. Intestinal epithelium and autophagy: Partners in gut homeostasis. Front. Immunol. 2013, 4, 1-14. [CrossRef] [PubMed]

105. Sarbassov, D.D.; Ali, S.M.; Sengupta, S.; Sheen, J.H.; Hsu, P.P.; Bagley, A.F.; Markhard, A.L.; Sabatini, D.M. Prolonged Rapamycin Treatment Inhibits mTORC2 Assembly and Akt/PKB. Mol. Cell 2006, 22, 159-168. [CrossRef] [PubMed]

106. Vivanco, I.; Sawyers, C. The phosphatidylinositol 3-Kinase-Akt pathway in human cancer. Nat. Rev. Cancer 2002, 2, 489-501. [CrossRef] [PubMed]

107. Nishimoto, T. Upstream and downstream of ran GTPase. Biol. Chem. 2004, 381, 397-405. [CrossRef] [PubMed]

108. Porta, C.; Paglino, C.; Mosca, A. Targeting PI3K/Akt/mTOR Signaling in Cancer. Front. Oncol. 2014, 4, 1-11. [CrossRef] [PubMed]

109. Hemmings, B.A.; Restuccia, D.F. PI3K-PKB/Akt Pathway. Cold Spring Harb. Perspect. Biol. 2012, 7, 1-4. [CrossRef] [PubMed]

110. Martini, M.; De Santis, M.C.; Braccini, L.; Gulluni, F.; Hirsch, E. PI3K/Akt signaling pathway and cancer: An updated review. Ann. Med. 2014, 34, 1-12. [CrossRef] [PubMed]

111. Franke, T.F. PI3K/Akt: Getting it right matters. Oncogene 2008, 27, 6473-6488. [CrossRef] [PubMed]

112. Vanhaesebroeck, B.; Alessi, D.R. The PI3K-PDK1 connection: More than just a road to PKB. Biochem. J. 2000, 346 Pt 3, 561-576. [CrossRef] [PubMed]

113. Vander Haar, E.; Lee, S.-I.; Bandhakavi, S.; Griffin, T.J.; Kim, D.-H. Insulin signalling to mTOR mediated by the Akt/PKB substrate PRAS40. Nat. Cell Biol. 2007, 9, 316-323. [CrossRef] [PubMed]

114. Sarbassov, D.D.; Guertin, D.A.; Ali, S.M.; Sabatini, D.M. Phosphorylation and regulation of Akt/PKB by the rictor-mTOR complex. Science 2005, 307, 1098-1101. [CrossRef] [PubMed]

115. Alessi, D.R.; James, S.R.; Downes, C.P.; Holmes, A.B.; Gaffney, P.R.; Reese, C.B.; Cohen, P. Characterization of a 3-phosphoinositide-dependent protein kinase which phosphorylates and activates protein kinase Balpha. Curr. Biol. 1997, 7, 261-269. [CrossRef]

116. Andjelković, M.; Jakubowicz, T.; Cron, P.; Ming, X.F.; Han, J.W.; Hemmings, B.A. Activation and phosphorylation of a pleckstrin homology domain containing protein kinase (RAC-PK/PKB) promoted by serum and protein phosphatase inhibitors. Proc. Natl. Acad. Sci. USA 1996, 93, 5699-5704. [CrossRef] [PubMed]

117. Brognard, J.; Sierecki, E.; Gao, T.; Newton, A.C. PHLPP and a Second Isoform, PHLPP2, Differentially Attenuate the Amplitude of Akt Signaling by Regulating Distinct Akt Isoforms. Mol. Cell 2007, 25, 917-931. [CrossRef] [PubMed]

118. Shaw, R.J.; Bardeesy, N.; Manning, B.D.; Lopez, L.; Kosmatka, M.; DePinho, R.A.; Cantley, L.C. The LKB1 tumor suppressor negatively regulates mTOR signaling. Cancer Cell 2004, 6, 91-99. [CrossRef] [PubMed]

119. Shackelford, D.B.; Shaw, R.J. The LKB1-AMPK pathway: Metabolism and growth control in tumour suppression. Nat. Rev. Cancer 2009, 9, 563-575. [CrossRef] [PubMed]

120. Ji, H.; Ramsey, M.R.; Hayes, D.N.; Fan, C.; McNamara, K.; Kozlowski, P.; Torrice, C.; Wu, M.C.; Shimamura, T.; Perera, S.A.; et al. LKB1 modulates lung cancer differentiation and metastasis. Nature 2007, 448, 807-810. [CrossRef] [PubMed]

121. Dong, L.; Sun, L.; Zhang, X.; Pan, L.; Lian, L.; Chen, Z.; Zhong, D. Negative regulation of mTOR activity by LKB1-AMPK signaling in non-small cell lung cancer cells. Acta Pharmacol. Sin. 2013, 34, 314-318. [CrossRef] [PubMed]

122. Woods, A.; Johnstone, S.R.; Dickerson, K.; Leiper, F.C.; Fryer, L.G.D.; Neumann, D.; Schlattner, U.; Wallimann, T.; Carlson, M.; Carling, D. LKB1 Is the Upstream Kinase in the AMP-Activated Protein Kinase Cascade. Curr. Biol. 2003, 13, 2004-2008. [CrossRef] [PubMed]

123. Jones, R.G.; Plas, D.R.; Kubek, S.; Buzzai, M.; Mu, J.; Xu, Y.; Birnbaum, M.J.; Thompson, C.B. AMP-activated protein kinase induces a p53-dependent metabolic checkpoint. Mol. Cell 2005, 18, 283-293. [CrossRef] [PubMed] 
124. Price, N.L.; Gomes, A.P.; Ling, A.J.Y.; Duarte, F.V.; Martin-Montalvo, A.; North, B.J.; Agarwal, B.; Ye, L.; Ramadori, G.; Teodoro, J.S.; et al. SIRT1 is required for AMPK activation and the beneficial effects of resveratrol on mitochondrial function. Cell Metab. 2012, 15, 675-690. [CrossRef] [PubMed]

125. Salminen, A.; Kaarniranta, K. AMP-activated protein kinase (AMPK) controls the aging process via an integrated signaling network. Ageing Res. Rev. 2012, 11, 230-241. [CrossRef] [PubMed]

126. Corradetti, M.N.; Inoki, K.; Bardeesy, N.; Depinho, R.A.; Guan, K. Regulation of the TSC pathway by LKB1: Evidence of a molecular link between tuberous sclerosis complex and Peutz-Jeghers syndrome service Regulation of the TSC pathway by LKB1: Evidence of a molecular link between tuberous sclerosis complex and Peutz-Je. Genes Dev. 2004, 18, 1533-1538. [CrossRef] [PubMed]

127. Inoki, K.; Zhu, T.; Guan, K.-L. TSC2 Mediates Cellular Energy Response to Control Cell Growth and Survival. Cell 2003, 115, 577-590. [CrossRef]

128. Gwinn, D.M.; Shackelford, D.B.; Egan, D.F.; Mihaylova, M.M.; Mery, A.; Vasquez, D.S.; Turk, B.E.; Shaw, R.J. AMPK Phosphorylation of Raptor Mediates a Metabolic Checkpoint. Mol. Cell 2008, 30, 214-226. [CrossRef] [PubMed]

129. Roach, P.J. AMPK-ULK1—Autophagy. Mol. Cell. Biol. 2011, 31, 3082-3084. [CrossRef] [PubMed]

130. Miyake, N.; Chikumi, H.; Takata, M.; Nakamoto, M.; Igishi, T.; Shimizu, E. Rapamycin induces p53-independent apoptosis through the mitochondrial pathway in non-small cell lung cancer cells. Oncol. Rep. 2012, 28, 848-854. [PubMed]

131. Wang, L.; Wang, R. Effect of rapamycin (RAPA) on the growth of lung cancer and its mechanism in mice with A549. Int. J. Clin. Exp. Pathol. 2015, 8, 9208-9213. [PubMed]

132. Kim, K.W.; Moretti, L.; Mitchell, L.R.; Jung, D.K.; Lu, B. Combined Bcl-2/mammalian target of rapamycin inhibition leads to enhanced radiosensitization via induction of apoptosis and autophagy in non-small cell lung tumor xenograft model. Clin. Cancer Res. 2009, 15, 6096-6105. [CrossRef] [PubMed]

133. Kawabata, S.; Chiang, C.; Tsurutani, J.; Shiga, H. Rapamycin downregulates thymidylate synthase and potentiates the activity of pemetrexed in non-small cell lung cancer. Oncotarget 2014, 5, 1062-1070. [CrossRef] [PubMed]

134. Xia, Y.; Liu, Y.-L.; Xie, Y.; Zhu, W.; Guerra, F.; Shen, S.; Yeddula, N.; Fischer, W.; Low, W.; Zhou, X.; et al. A combination therapy for KRAS-driven lung adenocarcinomas using lipophilic bisphosphonates and rapamycin. Sci. Transl. Med. 2014, 6, 263ra161. [CrossRef] [PubMed]

135. Gorzalczany, Y.; Gilad, Y.; Amihai, D.; Hammel, I.; Sagi-Eisenberg Ronit, R.; Merimsky, O. Combining an EGFR directed tyrosine kinase inhibitor with autophagy-inducing drugs: A beneficial strategy to combat non-small cell lung cancer. Cancer Lett. 2011, 310, 207-215. [CrossRef] [PubMed]

136. Fung, C.; Chen, X.; Grandis, J.R.; Duvvuri, U. EGFR tyrosine kinase inhibition induces autophagy in cancer cells. Cancer Biol. Ther. 2012, 13, 1417-1424. [CrossRef] [PubMed]

137. Chresta, C.M.; Davies, B.R.; Hickson, I.; Harding, T.; Cosulich, S.; Critchlow, S.E.; Vincent, J.P.; Ellston, R.; Jones, D.; Sini, P.; et al. AZD8055 is a potent, selective, and orally bioavailable ATP-competitive mammalian target of rapamycin kinase inhibitor with in vitro and in vivo antitumor activity. Cancer Res. 2010, 70, 288-298. [CrossRef] [PubMed]

138. Sini, P.; James, D.; Chresta, C.; Guichard, S. Simultaneous inhibition of mTORC1 and mTORC2 by mTOR kinase inhibitor AZD8055 induces autophagy and cell death in cancer cells. Autophagy 2010, 6, 553-554. [CrossRef] [PubMed]

139. Willems, L.; Chapuis, N.; Puissant, A.; Maciel, T.T.; Green, A.S.; Jacque, N.; Vignon, C.; Park, S.; Guichard, S.; Herault, O.; et al. The dual mTORC1 and mTORC2 inhibitor AZD8055 has anti-tumor activity in acute myeloid leukemia. Leukemia 2012, 26, 1195-1202. [CrossRef] [PubMed]

140. Jordan, N.J.; Dutkowski, C.M.; Barrow, D.; Mottram, H.J.; Hutcheson, I.R.; Nicholson, R.I.; Guichard, S.M.; Gee, J.M.W. Impact of dual mTORC1/2 mTOR kinase inhibitor AZD8055 on acquired endocrine resistance in breast cancer in vitro. Breast Cancer Res. 2014, 16, R12. [CrossRef]

141. Faber, A.C.; Li, D.; Song, Y.; Liang, M.C.; Yeap, B.Y.; Bronson, R.T.; Lifshits, E.; Chen, Z.; Maira, S.M.; Garcia-Echeverria, C.; et al. Differential induction of apoptosis in HER2 and EGFR addicted cancers following PI3K inhibition. Proc. Natl. Acad. Sci. USA 2009, 106, 19503-19508. [CrossRef] [PubMed]

142. Jin, H.O.; Lee, Y.H.; Park, J.A.; Kim, J.H.; Hong, S.E.; Kim, H.A.; Kim, E.K.; Noh, W.C.; Kim, B.H.; Ye, S.K.; et al. Blockage of Stat3 enhances the sensitivity of NSCLC cells to PI3K/mTOR inhibition. Biochem. Biophys. Res. Commun. 2014, 444, 502-508. [CrossRef] [PubMed] 
143. Xu, C.-X.; Zhao, L.; Yue, P.; Fang, G.; Tao, H.; Owonikoko, T.K.; Ramalingam, S.S.; Khuri, F.R.; Sun, S.-Y. Augmentation of NVP-BEZ235's anticancer activity against human lung cancer cells by blockage of autophagy. Cancer Biol. Ther. 2011, 12, 549-555. [CrossRef] [PubMed]

144. Elrod, H.A.; Lin, Y.-D.; Yue, P.; Wang, X.; Lonial, S.; Khuri, F.R.; Sun, S.-Y. The alkylphospholipid perifosine induces apoptosis of human lung cancer cells requiring inhibition of Akt and activation of the extrinsic apoptotic pathway. Mol. Cancer Ther. 2007, 6, 2029-2038. [CrossRef] [PubMed]

145. Fu, L.; Kim, Y.A.; Wang, X.; Wu, X.; Yue, P.; Lonial, S.; Khuri, F.R.; Sun, S.Y. Perifosine inhibits mammalian target of rapamycin signaling through facilitating degradation of major components in the mTOR axis and induces autophagy. Cancer Res. 2009, 69, 8967-8976. [CrossRef] [PubMed]

146. Sun, S.Y. Enhancing perifosine's anticancer efficacy by preventing autophagy. Autophagy 2010, 6, $184-185$. [CrossRef] [PubMed]

147. Jeong, E.H.; Choi, H.S.; Lee, T.G.; Kim, H.R.; Kim, C.H. Dual Inhibition of PI3K/Akt/mTOR Pathway and Role of Autophagy in Non-Small Cell Lung Cancer Cells. Tuberc. Respir. Dis. 2012, 72, 343-351. [CrossRef] [PubMed]

148. Dholaria, B.; Hammond, W.; Shreders, A.; Lou, Y. Emerging therapeutic agents for lung cancer. J. Hematol. Oncol. 2016, 9, 138. [CrossRef] [PubMed]

149. Yadav, R.K.; Chae, S.-W.; Kim, H.-R.; Chae, H.J. Endoplasmic reticulum stress and cancer. J. Cancer Prev. 2014, 19, 75-88. [CrossRef] [PubMed]

150. Mori, K. The unfolded protein response: The dawn of a new field. Proc. Jpn. Acad. Ser. B Phys. Biol. Sci. 2015, 91, 469-480. [CrossRef] [PubMed]

151. Hazari, Y.M.; Bashir, A.; Haq, E.U.; Fazili, K.M. Emerging tale of UPR and cancer: An essentiality for malignancy. Tumor Biol. 2016, 37, 14381-14390. [CrossRef] [PubMed]

152. Vattem, K.M.; Wek, R.C. Reinitiation involving upstream ORFs regulates ATF4 mRNA translation in mammalian cells. Proc. Natl. Acad. Sci. USA 2004, 101, 11264-11274. [CrossRef] [PubMed]

153. Lu, M.; Lawrence, D.A.; Marsters, S.; Acosta-Alvear, D.; Kimmig, P.; Mendez, A.S.; Paton, A.W.; Paton, J.C.; Walter, P.; Ashkenazi, A. Opposing unfolded-protein-response signals converge on death receptor 5 to control apoptosis. Science 2014, 345, 98-101. [CrossRef] [PubMed]

154. Liu, G.; Su, L.; Hao, X.; Zhong, N.; Zhong, D.; Singhal, S.; Liu, X. Salermide up-regulates death receptor 5 expression through the ATF4-ATF3-CHOP axis and leads to apoptosis in human cancer cells. J. Cell. Mol. Med. 2012, 16, 1618-1628. [CrossRef] [PubMed]

155. Yan, J.; Zhong, N.; Liu, G.; Chen, K.; Liu, X.; Su, L.; Singhal, S. Usp9x- and Noxa-mediated Mcl-1 downregulation contributes to pemetrexed-induced apoptosis in human non-small-cell lung cancer cells. Cell Death Dis. 2014, 5, e1316. [CrossRef] [PubMed]

156. Høyer-Hansen, M.; Bastholm, L.; Szyniarowski, P.; Campanella, M.; Szabadkai, G.; Farkas, T.; Bianchi, K.; Fehrenbacher, N.; Eling, F.; Rizzuto, R.; et al. Control of Macroautophagy by Calcium, Calmodulin-Dependent Kinase Kinase- $\beta$, and Bcl-2. Mol. Cell 2007, 25, 193-205. [CrossRef] [PubMed]

157. Wu, S.H.; Hang, L.W.; Yang, J.S.; Chen, H.Y.; Lin, H.Y.; Chiang, J.H.; Lu, C.C.; Yang, J.L.; Lai, T.Y.; Ko, Y.C.; et al. Curcumin induces apoptosis in human non-small cell lung cancer NCI-H460 cells through ER stress and caspase cascade- and mitochondria-dependent pathways. Anticancer Res. 2010, 30, 2125-2133. [PubMed]

158. Lin, S.S.; Huang, H.P.; Yang, J.S.; Wu, J.Y.; Hsai, T.C.; Lin, C.C.; Lin, C.W.; Kuo, C.L.; Gibson Wood, W.; Chung, J.G. DNA damage and endoplasmic reticulum stress mediated curcumin-induced cell cycle arrest and apoptosis in human lung carcinoma A-549 cells through the activation caspases cascade- and mitochondrial-dependent pathway. Cancer Lett. 2008, 272, 77-90. [CrossRef] [PubMed]

159. Pillai, G.R.; Srivastava, A.S.; Hassanein, T.I.; Chauhan, D.P.; Carrier, E. Induction of apoptosis in human lung cancer cells by curcumin. Cancer Lett. 2004, 208, 163-170. [CrossRef] [PubMed]

160. Xu, J.H.; Yang, H.P.; Zhou, X.D.; Wang, H.J.; Gong, L.; Tang, C.L. Autophagy Accompanied with Bisdemethoxycurcumin-induced Apoptosis in Non-small Cell Lung Cancer Cells. Biomed. Environ. Sci. 2015, 28, 105-115. [PubMed]

161. Lagisetty, P.; Vilekar, P.; Sahoo, K.; Anant, S.; Awasthi, V. CLEFMA—An anti-proliferative curcuminoid from structure-activity relationship studies on 3,5-bis(benzylidene)-4-piperidones. Bioorganic Med. Chem. 2010, 18, 6109-6120. [CrossRef] [PubMed] 
162. Li, T.; Su, L.; Zhong, N.; Hao, X.; Zhong, D.; Singhal, S.; Liu, X. Salinomycin induces cell death with autophagy through activation of endoplasmic reticulum stress in human cancer cells. Autophagy 2013, 9, 1057-1068. [CrossRef] [PubMed]

163. Lin, Y.; Wang, Y.; Liu, X.; Yan, J.; Su, L.; Liu, X. A novel derivative of tetrandrine (H1) induces endoplasmic reticulum stress-mediated apoptosis and prosurvival autophagy in human non-small cell lung cancer cells. Tumor Biol. 2016, 37, 10403-10413. [CrossRef] [PubMed]

164. Ma, G.; Luo, W.; Lu, J.; Ma, D.L.; Leung, C.H.; Wang, Y.; Chen, X. Cucurbitacin e induces caspase-dependent apoptosis and protective autophagy mediated by ROS in lung cancer cells. Chem. Biol. Interact. 2016, 253, 1-9. [CrossRef] [PubMed]

165. Tang, Z.H.; Zhang, L.L.; Li, T.; Lu, J.H.; Ma, D.L.; Leung, C.H.; Chen, X.P.; Jiang, H.L.; Wang, Y.T.; Lu, J.J. Glycyrrhetinic acid induces cytoprotective autophagy via the inositol-requiring enzyme 1alpha-c-Jun N-terminal kinase cascade in non-small cell lung cancer cells. Oncotarget 2015, 6, 43911-43926. [PubMed]

166. Tang, Z.H.; Chen, X.; Wang, Z.Y.; Chai, K.; Wang, Y.F.; Xu, X.H.; Wang, X.W.; Lu, J.H.; Wang, Y.T.; Chen, X.P.; et al. Induction of C/EBP homologous protein-mediated apoptosis and autophagy by licochalcone A in non-small cell lung cancer cells. Sci. Rep. 2016, 6, 26241. [CrossRef] [PubMed]

167. Yang, Y. Cancer immunotherapy: Harnessing the immune system to battle cancer. J. Clin. Investig. 2015, 125, 3335-3337. [CrossRef] [PubMed]

168. Pan, H.; Chen, L.; Xu, Y.; Han, W.; Lou, F.; Fei, W.; Liu, S.; Jing, Z.; Sui, X. Autophagy-associated immune responses and cancer immunotherapy. Oncotarget 2016, 7, 21235-21246. [PubMed]

169. Somasundaram, A.; Socinski, M.A.; Villaruz, L.C. Immune checkpoint blockade in lung cancer. Discov. Med. 2016, 22, 55-65. [PubMed]

170. De Mello, R.A.; Veloso, A.F.; Esrom, C.P.; Nadine, S.; Antoniou, G. Potential role of immunotherapy in advanced non-small-cell lung cancer. OncoTargets Ther. 2016, 10, 21-30. [CrossRef] [PubMed]

171. Drake, C.G. Combination immunotherapy approaches. Ann. Oncol. 2012, 23, viii41-viii46. [CrossRef] [PubMed]

172. Fang, L.; Wu, H.M.; Ding, P.S.; Liu, R.Y. TLR2 mediates phagocytosis and autophagy through JNK signaling pathway in Staphylococcus aureus-stimulated RAW264.7 cells. Cell. Signal. 2014, 26, 806-814. [CrossRef] [PubMed]

173. Anand, P.K.; Tait, S.W.; Lamkanfi, M.; Amer, A.O.; Nunez, G.; Pages, G.; Pouyssegur, J.; McGargill, M.A.; Green, D.R.; Kanneganti, T.D. TLR2 and RIP2 pathways mediate autophagy of Listeria monocytogenes via extracellular signal-regulated kinase (ERK) activation. J. Biol. Chem. 2011, 286, 42981-42991. [CrossRef] [PubMed]

174. Jia, W.; Pua, H.H.; Li, Q.J.; He, Y.W. Autophagy regulates endoplasmic reticulum homeostasis and calcium mobilization in T lymphocytes. J. Immunol. 2011, 186, 1564-1574. [CrossRef] [PubMed]

175. Miller, B.C.; Zhao, Z.; Stephenson, L.M.; Cadwell, K.; Pua, H.H.; Lee, H.K.; Mizushima, N.N.; Iwasaki, A.; He, Y.W.; Swat, W.; et al. The autophagy gene ATG5 plays an essential role in B lymphocyte development. Autophagy 2008, 4, 309-314. [CrossRef] [PubMed]

176. Nie, J.; Zhao, C.; Deng, L.I.; Chen, J.; Yu, B.; Wu, X.; Pang, P.; Chen, X. Efficacy of traditional Chinese medicine in treating cancer. Biomed. Rep. 2016, 4, 3-14. [CrossRef] [PubMed]

177. Ma, J.; Liu, J.; Lu, C.; Cai, D. Pachymic acid induces apoptosis via activating ROS-dependent JNK and ER stress pathways in lung cancer cells. Cancer Cell Int. 2015, 15, 78. [CrossRef] [PubMed]

178. Xu, W.S.; Dang, Y.Y.; Guo, J.J.; Wu, G.S.; Lu, J.J.; Chen, X.P.; Wang, Y.T. Furanodiene induces endoplasmic reticulum stress and presents antiproliferative activities in lung cancer cells. Evid. Based Complement. Altern. Med. 2012, 2012, 426521. [CrossRef] [PubMed]

179. Zhao, R.; Chen, M.; Jiang, Z.; Zhao, F.; Xi, B.; Zhang, X.; Fu, H.; Zhou, K. Platycodin-D Induced Autophagy in Non-Small Cell Lung Cancer Cells via PI3K/Akt/mTOR and MAPK Signaling Pathways. J. Cancer 2016, 6, 623-631. [CrossRef] [PubMed]

(c) 2017 by the authors; licensee MDPI, Basel, Switzerland. This article is an open access article distributed under the terms and conditions of the Creative Commons Attribution (CC BY) license (http:/ / creativecommons.org/licenses/by/4.0/). 